\title{
Neurobiological After-Effects of Low Intensity Transcranial Electric Stimulation of the Human Nervous System: From Basic Mechanisms to Metaplasticity
}

\author{
Sohaib Ali Korai ${ }^{1}$, Federico Ranieri ${ }^{2}$, Vincenzo Di Lazzaro ${ }^{3}$, Michele Papa ${ }^{1,4}$ and \\ Giovanni Cirillo ${ }^{1,2 *}$ \\ ${ }^{1}$ Division of Human Anatomy - Laboratory of Neuronal Networks, University of Campania "Luigi Vanvitelli", Naples, Italy, \\ ${ }^{2}$ Neurology Unit, Department of Neurosciences, Biomedicine and Movement Sciences, University of Verona, Verona, Italy, \\ ${ }^{3}$ Neurology, Neurophysiology and Neurobiology Unit, University Campus Bio-Medico, Rome, Italy, ${ }^{4}$ ISBE Italy, SYSBIO \\ Centre of Systems Biology, Milan, Italy
}

OPEN ACCESS

Edited by:

Carol Di Perri,

University of Edinburgh

United Kingdom

Reviewed by:

Antonio Suppa

Sapienza University of Rome, Italy

Carlo Cavaliere

Institute of Research and Medical

Care (IRCCS) SDN, Italy

*Correspondence:

Giovanni Cirillo

giovanni.cirillo@unicampania.it

Specialty section:

This article was submitted to

Neurorehabilitation,

a section of the journal

Frontiers in Neurology

Received: 27 July 2020 Accepted: 04 January 2021

Published: 15 February 2021

Citation:

Korai SA, Ranieri F, Di Lazzaro V.

Papa M and Cirillo G (2021) Neurobiological After-Effects of Low

Intensity Transcranial Electric

Stimulation of the Human Nervous System: From Basic Mechanisms to

Metaplasticity.

Front. Neurol. 12:587771.

doi: 10.3389/fneur.2021.587771
Non-invasive low-intensity transcranial electrical stimulation (tES) of the brain is an evolving field that has brought remarkable attention in the past few decades for its ability to directly modulate specific brain functions. Neurobiological after-effects of tES seems to be related to changes in neuronal and synaptic excitability and plasticity, however mechanisms are still far from being elucidated. We aim to review recent results from in vitro and in vivo studies that highlight molecular and cellular mechanisms of transcranial direct (tDCS) and alternating (tACS) current stimulation. Changes in membrane potential and neural synchronization explain the ongoing and short-lasting effects of tES, while changes induced in existing proteins and new protein synthesis is required for long-lasting plastic changes (LTP/LTD). Glial cells, for decades supporting elements, are now considered constitutive part of the synapse and might contribute to the mechanisms of synaptic plasticity. This review brings into focus the neurobiological mechanisms and after-effects of tDCS and tACS from in vitro and in vivo studies, in both animals and humans, highlighting possible pathways for the development of targeted therapeutic applications.

Keywords: transcranial direct current stimulation, transcranial alternating current stimulation, neurobiological after-effects, synaptic plasiticty, non-invasive brain stimulation

\section{INTRODUCTION}

In the last two decades, therapeutic efficacy of non-invasive transcranial brain stimulation techniques through low-intensity electrical fields has been demonstrated by a number of works and clinical trials providing promising results for many neurological disorders, including stroke (1) and epilepsy (2,3), movement disorders/Parkinson's (PD) (4) and Alzheimer's (AD) $(5,6)$. Due to non-invasiveness and transient side effects (7), transcranial electrical stimulation (tES) has found progressively a wide field of applications. Moreover, acquisition of recent experimental data has extended our knowledge of the cellular and molecular mechanisms involved in the after-effects of tES, thus supporting its therapeutic potential for brain disorders based on impaired synaptic plasticity (2). 
The basic principle of tES is very simple and based on the negative (anodal) and positive (cathodal) currents and their flow into the brain (8). However, neurobiological mechanisms and after-effects are not yet fully understood. Experimental evidence has demonstrated that weak low-intensity ES (at an intensity lower than that needed for triggering action potentials) induces polarity-specific changes in spontaneous and evoked neuronal activity $(9,10)$ : anodal polarization increases neuronal activity, whereas cathodal polarization decreases it (11-14). Accordingly, transcranial direct current stimulation (tDCS) has been shown to induce long-lasting and polarity-specific changes of human motor cortex excitability (15-17) related to modifications of synaptic efficacy similar to those underlying long-term potentiation (LTP) and long-term depression (LTD) of synaptic activity $(18,19)$. Studies of the effects of direct current stimulation (DCS) in slices of mouse primary motor cortex have shown that anodal DCS, in the absence of simultaneous synaptic activation, does not induce LTP/LTD like changes but it can modulate LTP induction (20). In contrast, by coupling DCS with low frequency stimulation (at $0.1 \mathrm{~Hz}$ ), a long-lasting polarity- (anodal DCS) and frequency- specific LTP is obtained, mainly depending on N-methyl-D- aspartate (NMDA) receptor activation and secretion of brain-derived neurotrophic factor (BDNF) (21). In summary, these studies highlight the complex nature of tDCS effects, characterized by the capability of inducing and modulating LTP/LTD. However, while the immediate effects of tES can be explained by changes in transmembrane potential influencing neuronal firing, it is plausible that the long-term after-effects are likely due to modifications of intracellular calcium dynamics and mechanisms of synaptic plasticity, based on LTP/LTD processes $(18,22,23)$ and/or induction of metaplasticity, the activity-dependent physiological changes that modulate neural plasticity (24). Anodal tDCS, for example, induces neurotrophic BDNF-mediated priming after-effects on synaptic plasticity and memory, making synapses susceptible to LTP induction in the rat hippocampus (25).

This work aims to comprehensively summarize the neurobiological mechanisms of tES and discuss future clinical applications. In particular, we first analyzed the technical aspects of electrical stimulation techniques, and then the neurobiological after-effects of tES on the constituents of the synaptic structure, distinguishing those on membrane polarity, neural transmission, synaptic plasticity, neuronal network and connectivity, and finally the effects on glial cells and neuroinflammation.

We believe that understanding the basis of the modulatory effect of tES would be particularly relevant for its clinical application in humans, where it could be used to shape the plastic properties of the brain.

\section{TECHNICAL ASPECTS: TRANSCRANIAL CURRENT AND MAGNETIC STIMULATION}

According to whether direct or alternating current is applied to the brain, the method is referred to as either transcranial

Abbreviations: $\boldsymbol{t} E S$, transcranial electrical stimulation. direct current stimulation (tDCS) or transcranial alternating current stimulation (tACS). Both techniques produce effects on cortical excitability outlasting the stimulation, up to $3 \mathrm{~h}$ with tDCS (26) and up to $1 \mathrm{~h}$ with high-frequency tACS (2729). TDCS acts in a polarity-dependent fashion, with anodal stimulation increasing and cathodal stimulation decreasing neuronal excitability, whereas tACS consists in the application of a sinusoidal waveform current that alternates between the anode and the cathode (switching polarity) and modulates the power of oscillatory rhythms in a frequency-dependent manner by synchronizing or desynchronizing neuronal networks (30). For example, in studies that coupled transcranial magnetic stimulation (TMS) with ES, tACS was found to synchronize cortical networks bursting at frequencies higher than $300 \mathrm{~Hz}(31)$.

The association between the type of stimulation and neural response depends on many physical properties including the electrode type, length, strength, and frequency of stimulation (32). Low-intensity, constant, or non-constant currents are used for tDCS and delivered in rectangular or sinusoidal waves with pulses of unidirectional current, whilst non-constant current is used for tACS (33). TDCS flows into the brain from a battery-powered generator through a couple of sponge electrodes, with one or both the electrodes fixed over the scalp. It has been demonstrated that current density (i.e., current intensity/electrode size), duration, polarity, and location of stimulating electrodes have important implications in the modulatory outcome of stimulation (34). Generally, tDCS does not involve synaptic effects but polarity changes of the membrane resting potential, does not induce neuronal firing but rather modulates spontaneous neuronal network activity, polarizing brain tissue (35-37). The two types of stimulation, anodal and cathodal, do not contrast each other in terms of after-effects and modulation of their intensity dramatically produces different results. Generally, the cortical excitability is increased by anodal tDCS while it is decreased by the cathodal tDCS over the same area (site specificity).

TACS is a non-constant current which alternates its pulses with the opposite amplitude $(38,39)$. Despite site specificity, its effects are not site limited as tACS influences other areas of the brain through interneuronal circuits (33) and directly interferes with ongoing brain oscillations (40). TACS shares the same setup of tDCS: it is applied between electrodes placed over the target scalp sites, with intensity in the same range of 1-2 mA. The physiological bases of tACS are less explored than tDCS. The main biophysical (electric field strength and spatial distribution) and polarizing properties of tDCS should also apply to tACS, with the main difference that the polarity (i.e., the direction of current flow) changes of $180^{\circ}$ during each cycle of the sinusoidal waveform of tACS and that the maximum current flow is present only at the peak of the alternating current.

The advantage of tACS is that it allows the manipulation of amplitude, frequency, and coherence of intrinsic neuronal oscillations $(41,42)$. In addition, the effects of tACS could be translated into whole larger brain-network activity through five different neuronal mechanisms $(43,44)$ : (1) stochastic resonance, consisting in the stochastic response of tACS-affected neurons to be either polarized or hyperpolarized; (2) rhythm resonance, 
synchronizing tACS frequency with the endogenous oscillations; (3) temporal biasing of spikes, a synergistically excitation of the same groups of neurons during each cycle of stimulation; (4) network entrainment of an endogenous irregular neuronal activity that necessitates an external current with sufficiently stronger amplitude; (5) imposed pattern, tACS overcomes endogenous regular oscillations and introduce a new oscillation. These mechanisms attribute the large-scale effects of tACS to two synergistic phenomena: entrainment and neuroplasticity, respectively. The first takes place when an external rhythmic system affects another one, forcing it to follow its own oscillating frequency and phase; the second, through LTP/LTD phenomena, elicits offline tACS effects by increasing or decreasing neural synchronization, as confirmed by many studies $(29,45-47)$.

TACS has diverse modes of administration in terms of frequency: the beta $(20 \mathrm{~Hz})$, alpha $(10-12 \mathrm{~Hz})$, and gamma range $(40 \mathrm{~Hz})$, each producing diverse neurobiological effects for modulation of different bands of neural oscillations (42). The effects of alpha and gamma stimulation have been studied on attention with gamma stimulation demonstrating to facilitate endogenous attention (48).

Experimental and clinical applications of transcranial magnetic stimulation (TMS) is widely and progressively increased over the past two decades. In particular, several repetitive TMS (rTMS) protocols have been proved to modulate brain functions (from the molecular to the network scale) and human behavior $(49,50)$. For example, application of simple rTMS to a target cortical area for several minutes induces after-effects in a frequency- dependent manner (low frequency, $\leq 1 \mathrm{~Hz}$, reduces cortical excitability whereas high-frequency, $>5 \mathrm{~Hz}$, does the opposite) (51) while theta-burst stimulation (TBS), a patterned protocol, induces longer-lasting effects with shorter application time (continuous TBS has primarily an inhibitory effect on corticospinal excitability, while intermittent TBS has an excitatory effect) (52).

TMS shares fundamental similarities with tES as both share neurobiological modulations at similar levels and involve rapid changes in magnetic fields (53). While TMS requires passing of current through coils to generate a magnetic field that in turn generates an electric field and a current density, in tES the electric field and the current density are proportional to injected current (54).

\section{NEUROBIOLOGICAL AFTER-EFFECTS OF CURRENT STIMULATION OF CENTRAL NERVOUS SYSTEM}

\section{Effects on Membrane Polarity}

Table 1 summarizes the results of the studies that analyzed the effects of tES on membrane polarity. Evidence has demonstrated that tDCS can modify neuronal membrane polarity and therefore the action potential generation $(15,19,55)$ through activation of voltage-gated pre and postsynaptic $\mathrm{Na}^{+}$and $\mathrm{Ca}^{2+}$ channels thus causing increased presynaptic release of excitatory neurotransmitters and postsynaptic calcium influx, respectively
TABLE 1 | tES after-effects on membrane polarity.

\begin{tabular}{|c|c|c|c|}
\hline References/Study & $\begin{array}{l}\text { Methodology } \\
\text { tES }\end{array}$ & Targets & Main results \\
\hline $\begin{array}{l}\text { Nitsche and } \\
\text { Paulus (15); } \\
\text { Liebetanz (19); } \\
\text { Stagg and Nitsche } \\
\text { (55) }\end{array}$ & tDCS & $\begin{array}{l}\text { Pre/post } \\
\text { synaptic } \mathrm{Na}^{+} \\
\text {and } \mathrm{Ca}^{2+} \\
\text { channels }\end{array}$ & $\begin{array}{l}\text { tDCS generates action } \\
\text { potential via } \mathrm{Na}^{+} \text {and } \\
\mathrm{Ca}^{2+} \text { channels by } \\
\text { increasing presynaptic } \\
\text { release of excitatory } \\
\text { transmitters and } \mathrm{Ca}^{2+} \\
\text { influx }\end{array}$ \\
\hline $\begin{array}{l}\text { Zaghi et al. (33); } \\
\text { Bikson et al. (56) }\end{array}$ & tDCS & $\begin{array}{l}\text { Hippocampal } \\
\text { neurons }\end{array}$ & $\begin{array}{l}\text { Somatic polarization } \\
\text { was obtained with } \\
\text { electric field parallel to } \\
\text { somato-dendritic axis } \\
\text { in hippocampal } \\
\text { neurons }\end{array}$ \\
\hline $\begin{array}{l}\text { Bikson et al. (56); } \\
\text { Arlotti et al. (57); } \\
\text { Rahman et al. (58); } \\
\text { Pelletier and } \\
\text { Cicchetti (32); Seo } \\
\text { and Jun (59) }\end{array}$ & $\begin{array}{l}\text { tDCS } \\
- \text { aDCS } \\
\text { - cDCS }\end{array}$ & $\begin{array}{l}\text { Structural } \\
\text { components } \\
\text { of neurons }\end{array}$ & $\begin{array}{l}\text { Components at the } \\
\text { cathode depolarize } \\
\text { while those at the } \\
\text { anode hyperpolarize }\end{array}$ \\
\hline $\begin{array}{l}\text { Francis et al. (60); } \\
\text { Deans et al. (61); } \\
\text { Reato et al. (62) }\end{array}$ & tACS & $\begin{array}{l}\text { Neuronal } \\
\text { resonance }\end{array}$ & $\begin{array}{l}\text { tACS can induce } \\
\text { cumulative effects over } \\
\text { multiple cycles that can } \\
\text { shift in spike timing. }\end{array}$ \\
\hline $\begin{array}{l}\text { Bindman et al. } \\
\text { (11); Bikson et al. } \\
\text { (56); Antal and } \\
\text { Herrmann (63) }\end{array}$ & $\begin{array}{l}\text { tDCS } \\
- \text { aDCS } \\
- \text { cDCS }\end{array}$ & $\begin{array}{l}\text { Transmembrane } \\
\text { potentials }\end{array}$ & $\begin{array}{l}\text { Constant electric field } \\
\text { shifts neuronal } \\
\text { transmembrane } \\
\text { potential to less } \\
\text { negative in cDCS and } \\
\text { more negative in aDCS } \\
\text { which makes it more } \\
\text { prone to generate } \\
\text { action potential. }\end{array}$ \\
\hline
\end{tabular}

tES, transcranial electrical stimulation; tDCS, transcranial direct current stimulation; tACS, transcranial alternating current stimulation; a/c tDCS, anodal/cathodal transcranial direct current stimulation.

(15). Moderate but prolonged intracellular $\mathrm{Ca}^{2+}$ increase causes LTD while short but large $\mathrm{Ca}^{2+}$ increase causes LTP (64).

The polarity-dependent effect of tDCS is strictly dependent on the orientation of axons and dendrites (33). Specifically, when the effect of polarity was studied in vitro on hippocampal neurons (56), somatic polarization was obtained with the electric field parallel to the somato-dendritic axis, while an effect on afferents without somatic polarization was produced by the electric field perpendicular to the apical-dendritic axis. Moreover, the structural components of the cell at the cathode depolarize while the elements facing the anode are subject to hyperpolarization (32, 56-59). On the other hand, tACS, matching resonant neuronal properties, can induce cumulative effects over multiple cycles that may cause shift in spike timing (60-62).

However, these biophysical properties might produce complex modulatory effects when tES is applied to circuits of the human brain with no uniform spatial orientations. Based on experimental studies $(11,56)$, the applied constant electric field shifts the transmembrane potential of neurons toward less negative (anodal stimulation) or more negative values (cathodal 
stimulation), thus increasing or decreasing the likelihood of generation of action potentials (63), thus influencing both spontaneous and evoked neuronal firing.

\section{Effects on Neural Transmissions}

Many studies have shown that tACS interferes with several neurotransmitter systems. The balance between cholinergic and adrenergic system after administration of reserpine (an anti-adrenergic drug that irreversibly blocks the $\mathrm{H}^{+}$-coupled vesicular monoamine transporters-VMAT) and physostigmine (a parasympathomimetic reversible cholinesterase inhibitor) occurred much faster while applying tACS: it was observed that the quantity of presynaptic vesicles first declined, then increased after $5 \mathrm{~min}$ and then returned to baseline levels after tACS (65). Evidence suggested that this type of stimulation might modulate the serotoninergic raphe nuclei, the noradrenergic locus coeruleus, the cholinergic latero-dorsal tegmental, and pedunculopontine nuclei in the brainstem (66). Additionally, tACS was found to modulate the levels of endorphins into the cerebrospinal fluid (67) and naloxone, a pure opioid antagonist, was reported to reduce tACS analgesic effects (67), prompting to hypothesize a tACS-induced modulation of the neurotransmitters' release.

The blockage of serotonin reuptake increases LTP in the motor cortex by anodal tDCS and shifts LTD to LTP after cathodal tDCS (68). In addition, anodal tDCS was demonstrated to reduce $\gamma$-aminobutyric acid (GABA) concentration in the stimulated cerebral cortex while cathodal tDCS impaired glutamatergic neuronal activity and reduced GABA concentration $(2,69)$. Authors argue that these protocols might be used therapeutically to reduce the imbalance between excitatory and inhibitory transmitters $(70,71)$. These results were also confirmed in humans by magnetic resonance spectroscopy (MRS) studies examining the effects of tDCS on the hand area of the primary motor cortex. Accordingly, authors reported that anodal tDCS causes GABA decrease while cathodal tDCS decreases both the levels of glutamate and GABA (70). Upon administration of GABA antagonists, anodal tDCS produces delayed but enhanced excitability increase in cortical or subcortical areas (72). See Table 2 for a summary of the studies that analyzed the effects of tES on neural transmissions.

\section{Effects on Synaptic Plasticity}

Experimental and human studies suggest that the after-effects of tES might originate from persistent modifications of synaptic efficacy similar to those underlying LTP and LTD of synaptic activity $(18,19,73)$. Synaptic plasticity usually involves shortand long-term modifications of existing synapses (formation, removal, and remodeling of synapses and dendritic spines) that in turn modify the activity of brain networks in which they are interposed (50). Mechanisms of synaptic plasticity occur at different levels, from ultrastructural to synapse: calcium dynamics, neurotransmitter release, proteins (receptors, transporters, and ion channels) and gene expression (74). Table 3 summarizes the main results of the studies that analyzed the tES after-effects on synaptic plasticity.
TABLE 2 | tES after-effects on neural transmission.

\begin{tabular}{|c|c|c|c|}
\hline References/Study & $\begin{array}{l}\text { Methodology } \\
\text { tES }\end{array}$ & Targets & Main results \\
\hline $\begin{array}{l}\text { Kirsch and Nichols } \\
\text { (65) }\end{array}$ & tACS & $\begin{array}{l}\text { Cholinergic } \\
\text { and } \\
\text { adrenergic } \\
\text { neural } \\
\text { transmission }\end{array}$ & $\begin{array}{l}\text { After administration of } \\
\text { reserpine and } \\
\text { physostigmine and } \\
\text { administration of tACS, } \\
\text { the quantity of } \\
\text { presynaptic vesicles } \\
\text { declines and then } \\
\text { increased }\end{array}$ \\
\hline Nitsche et al. (68) & $\begin{array}{l}\text { tDCS } \\
- \text { aDCS } \\
- \text { cDCS }\end{array}$ & Motor cortex & $\begin{array}{l}\text { Blockage of serotonin } \\
\text { reuptake increases LTP } \\
\text { via aDCS and shifts } \\
\text { LTD to LTP after cDCS }\end{array}$ \\
\hline $\begin{array}{l}\text { Stagg et al. (70); } \\
\text { Nitsche et al. (72) }\end{array}$ & $\begin{array}{l}\text { tDCS } \\
- \text { aDCS } \\
- \text { cDCS }\end{array}$ & $\begin{array}{l}\text { GABA and } \\
\text { glutamate in } \\
\text { cortical and } \\
\text { subcortical } \\
\text { areas }\end{array}$ & $\begin{array}{l}\text { aDCS reduces GABA } \\
\text { while cDCS reduces } \\
\text { both glutamate and } \\
\text { GABA. With GABA } \\
\text { antagonists, aDCS } \\
\text { produced enhanced } \\
\text { excitability in cortical } \\
\text { and subcortical areas }\end{array}$ \\
\hline
\end{tabular}

tES, transcranial electrical stimulation; tDCS, transcranial direct current stimulation; tACS, transcranial alternating current stimulation; a/c tDCS, anodal/cathodal transcranial direct current stimulation; LTP, long-term potentiation; LTD, long-term depression; GABA, gamma amino butirric acid.

Experimental evidence using a high frequency pre-synaptic stimulation protocol has showed a polarity-specificity of tDCS in the modulation of LTP induction, with anodal stimulation increasing and cathodal stimulation decreasing the amount of LTP (20). These data suggest that tDCS alone is not capable of changing synaptic strength (i.e., inducing LTP), but rather that tDCS changes the propensity of the synapse to undergo LTP. Accordingly, in the study by Fritsch and colleagues, LTP was obtained after a conditioning anodal tDCS protocol but only in the presence of concomitant synaptic activation by presynaptic inputs (21).

Neurotrophins (BDNF, NGF, NT-3, and NT-4/5) are a large family of complex proteins that regulate several functions, including neuronal survival, differentiation, synaptic function, and plasticity but also neuronal death through interaction with two types of receptors, the tyrosine kinase receptors (TrkA, TrkB, and TrkC) and the common p75NTR receptor (82). Most of neurotrophins, including BDNF, is secreted in an immature form and then converted into the mature, active form by a complex fine-regulated system of proteases (83-85). With this premise, it has been demonstrated that tDCS might increase BDNF concentration when combined with presynaptic stimulation (21) inducing LTP via BDNF/TrkB signaling (25). TrkB stimulation by BDNF also promotes long-lasting synaptic potentiation and late phase LTP requires the conversion of pro-BDNF into mature BDNF in the hippocampus (21). Moreover, enhanced LTP in animals undergoing continuous tDCS can be reduced by TrkB antagonist (86) and anodal tDCS enhances hippocampal LTP and memory via chromatin remodeling of the Bdnf gene regulatory 
TABLE 3 | tES after-effects on synaptic plasticity.

\begin{tabular}{|c|c|c|c|}
\hline References/Study & $\begin{array}{l}\text { Methodology } \\
\text { tES }\end{array}$ & Targets & Main results \\
\hline Ranieri et al. (20) & $\begin{array}{l}\text { tDCS } \\
- \text { cDCS } \\
- \text { aDCS }\end{array}$ & Neuronal LTP & aDCS increased LTP while cDCS decreased LTP \\
\hline $\begin{array}{l}\text { Fritsch et al. (21); Yu et al. } \\
\text { (25) }\end{array}$ & tDCS & BDNF/TrkB signaling & $\begin{array}{l}\text { tDCS increases BDNF concentration which induces LTP. TrkB } \\
\text { stimulation by BDNF promotes late phase LTP }\end{array}$ \\
\hline $\begin{array}{l}\text { Lanté et al. (75); Luscher } \\
\text { and Malenka (76) }\end{array}$ & tDCS & NMDA/AMPA receptors & $\begin{array}{l}\text { High frequency stimulation induced LTP in active NMDA } \\
\text { receptors, expression of AMPA receptors in postsynaptic } \\
\text { neuron and } \mathrm{Ca}^{2+} \text { rise. Low frequency stimulation induces } \\
\text { small rise in } \mathrm{Ca}^{2+} \text { and presynaptic internalization of AMPA by } \\
\text { phosphatase activation and LTD generation }\end{array}$ \\
\hline $\begin{array}{l}\text { Mycielska and Djamgoz } \\
\text { (77); McCaig et al. (78) }\end{array}$ & tDCS & Cellular migration & $\begin{array}{l}\text { tDCS modified the speed and direction of cell migration by } \\
\text { shifting intracellular } \mathrm{Ca}^{2+} \text { and modifying expression of EGFR } \\
\text { due to electrostatic effects }\end{array}$ \\
\hline $\begin{array}{l}\text { Monte-Silva et al. (79); Kuo } \\
\text { et al. (80) }\end{array}$ & $\begin{array}{l}\text { tDCS } \\
- \text { cDCS } \\
- \text { aDCS }\end{array}$ & $\begin{array}{l}\text { L-DOPA induced plastic } \\
\text { changes }\end{array}$ & $\begin{array}{l}\text { Anodal L-DOPA suppressed plasticity induced by atDCS } \\
\text { while prolonged the reduction of excitability by cDCS }\end{array}$ \\
\hline Hurley and Machado (6) & tDCS & Neuronal polarity & $\begin{array}{l}\text { When synaptic activity is preconditioned by tDCS, continuous } \\
\text { tDCS after interval will modulate polarity }\end{array}$ \\
\hline Carvalho et al. (81) & $\begin{array}{l}\text { tDCS } \\
- \text { aDCS } \\
- \text { cDCS }\end{array}$ & Working memory & $\begin{array}{l}\text { Continuous aDCS facilitates performance and cDCS } \\
\text { enhances working memory }\end{array}$ \\
\hline Zaehle et al. (45) & tACS & $\begin{array}{l}\text { Rhythmic patterns and } \\
\text { natural pattern }\end{array}$ & $\begin{array}{l}\text { tACS modulates neural synchronization by increasing or } \\
\text { decreasing it and induces LTP and LTD }\end{array}$ \\
\hline
\end{tabular}

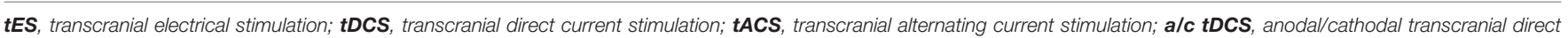

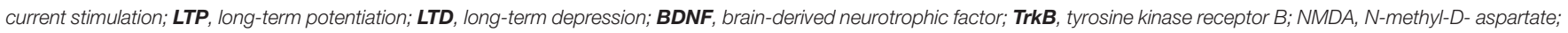
AMPA, alpha-amino-3-hydroxy-5-methyl-4-isoxazolepropionic acid.

sequence, increasing the expression of this gene (87). In addition, through TrkB/Fyn signaling, BDNF induces a phosphorylationdependent enhancement of NMDA receptor activity that further enhances effects of tDCS on LTP $(88,89)$.

The most prominent phenomena mediating LTP/LTD are the functional state of the synapse, $\mathrm{Ca}^{2+}$ signals and activity of NMDA glutamate receptors (74) (Figure 1). High-frequency current stimulation, in fact, induces LTP only in active synapses, which express active/open NMDA receptors, rapid expression of alpha-amino-3-hydroxy-5-methyl-4-isoxazolepropionic acid (AMPA) receptors in the postsynaptic neuron, and fast intracellular $\mathrm{Ca}^{2+}$ increase (90). In contrast, low-frequency, long-lasting stimulation induces small and slow rise in $\mathrm{Ca}^{2+}$ concentration, presynaptic internalization of AMPA receptors by phosphatase activation (that reduces glutamate sensitivity), and LTD generation $(75,76)$.

Studies have showed the tDCS induces changes in the direction and speed of cell migration which may be related to the shift of intracellular $\mathrm{Ca}^{2+}(77,78)$ and to changes in the expression of the epidermal growth factor receptors' (EGFR) due to electrostatic effects of tDCS, ultimately contributing to long-term modulation (78).

The effects of tES on synaptic plasticity are also modulated by concomitant administration of drugs acting on neural transmissions. The dopaminergic, cholinergic, serotonergic systems all affect tDCS-induced plasticity (91) in a dosedependent manner. For example, low dose administration of the D2/D3 agonist ropinirole abolishes plasticity (91), medium dosed ropinirole reestablishes facilitatory and inhibitory plasticity, whilst high dosage decreases facilitatory plasticity (92). Administration of low dosage or high dosage of anodal L-DOPA suppressed the plasticity induced by tDCS (79), however LDOPA prolonged the reduction of excitability induced by cathodal tDCS (80).

Induction of plasticity through tES, however, might also arise from simultaneous stimulation of the different components of the neural circuit, from the excitatory/inhibitory synapses to different brain networks, therefore, as a result, it is important to consider the main excitatory (LTP-like) or inhibitory (LTDlike) effect of the brain stimulation. Early LTP/LTD modifications usually last for 30-60 min after induction and reflect posttranscriptional modifications of pre-existing proteins, such as protein phosphorylation, in contrast late LTP/LTD could last hours, days, and even months and require genes and proteins expression (e.g., glutamate NMDA and metabotropic receptors) (50).

In order to shed light on the pathways leading to the synthesis of new proteins, attention has been focused on the group of immediate early genes (IEGs), that are rapidly induced following neuronal activation and are thought to be involved in the maintenance of $\operatorname{LTP}(93,94)$. Among IEGs, zif268 is likely to be specifically related to LTP, since it is expressed under virtually all LTP-inducing situations and shows a high correlation with the duration of LTP (95). After application of 


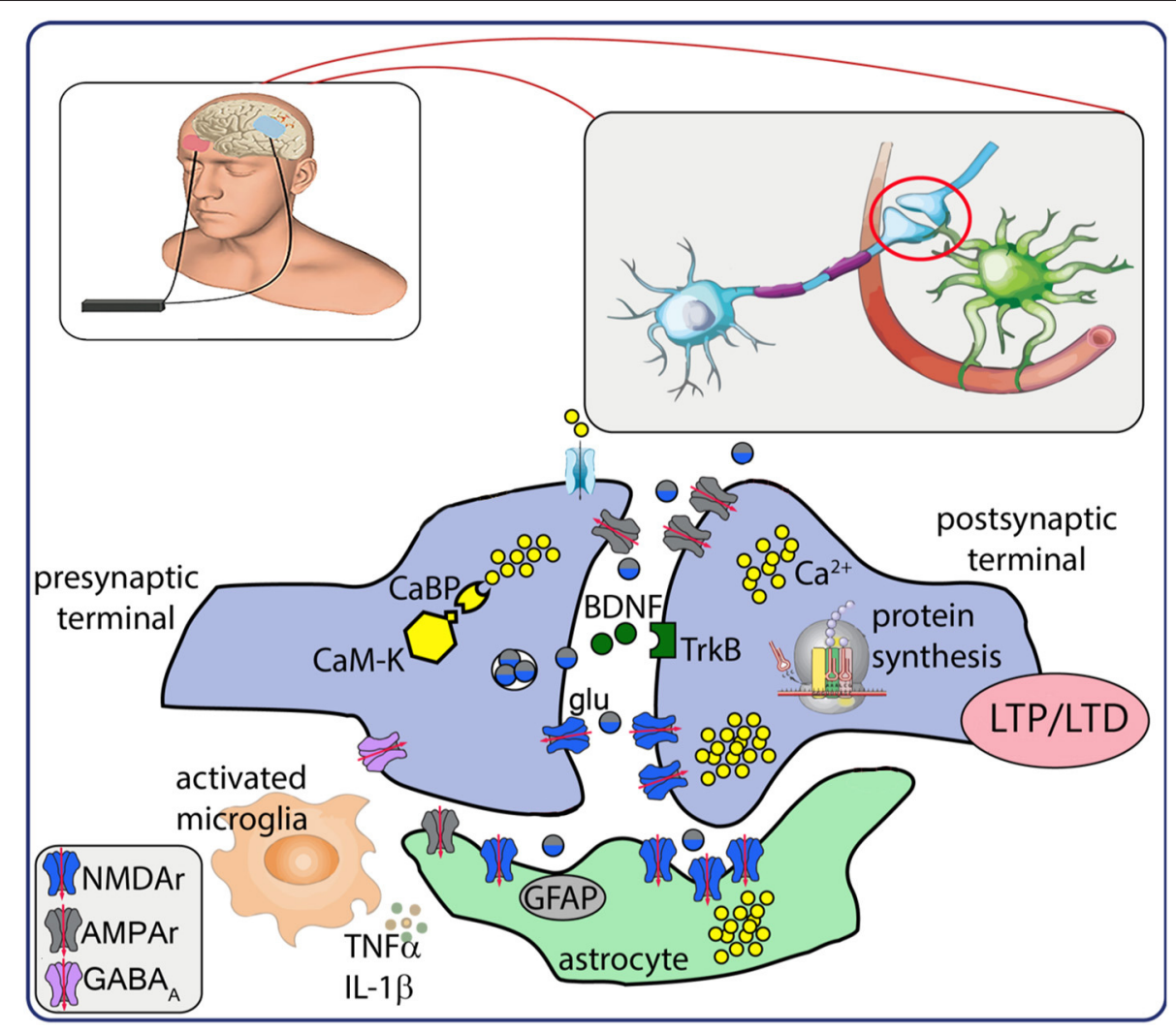

FIGURE 1 | Schematic representation of neurobiological after-effects of transcranial electrical stimulation (tES). tES induces intracellular Ca ${ }^{2+}$ increase and activation of $\mathrm{Ca}^{2+}$-dependent enzymes (CaM-K). Presynaptic mechanisms result in glutamate release that activates AMPA/NMDA receptors, modulates BDNF release and interaction with TrkB receptor, responsible for a cascade of intracellular events that lead to de novo protein synthesis. Electrical stimulation also modulates activation of astrocytes and neuroinflammatory response. Altogether, these mechanisms may underlie the establishment of LTP/LTD. CaBP, $\mathrm{Ca}^{2+}$ binding proteins; CaM-K, Ca ${ }^{2+}$ kinases; glu, glutamate; BDNF, brain-derived neurotrophic factor; TrkB, tyrosine kinase receptor B; LTP/LTD, long term potentiation/depression; GFAP, glial fibrillary acidic protein; TNF $\alpha$, tumor necrosis factor $\alpha$; IL-1 $\beta$, interleukin 1 $\beta$; NMDAr, N-methyl-D- aspartate receptor; AMPAr, alpha-amino-3-hydroxy-5-methyl-4-isoxazolep ropionic acid receptor; $\mathbf{G A B A}_{\mathbf{A}}$, gamma amino butirric acid $\mathrm{A}$ receptor.

both anodal and cathodal DCS to hippocampal rat brain slices, zif268 expression was increased, pointing to a possible initial role of zif268 in a cascade of activation of other downstream target genes (20).

Abnormally high activity and hyperexcitability of some subcortical pathways, as in the case of after stroke or during central nervous system (CNS) development, may respond to tES that modulates homeostatic plasticity of the hyperexcitable tissue (96-99). The hyperexcitability is maintained because neurons receive deficient inputs and, in order to compensate, increase excitatory synaptic strength and intrinsic excitability $(100,101)$.

In addition, metaplastic changes are observed with the administration of tES (6). The term metaplasticity refers to a higher order form of plasticity and reflects the activity-dependent physiological changes that modulate neural plasticity (102). The history of synaptic or cellular activity influences the direction and degree of synaptic plasticity, favoring or inhibiting plasticity induction, synaptic stabilization, and homeostatic regulation of cellular activity (103). Therefore, metaplasticity acts to avoid excessive synaptic strengthening or weakening, to maintain a relatively stable equilibrium of the neural activity in space and time (homeostatic synaptic plasticity), adjusting the balance between synaptic input and neuronal firing, and to prolong the time-window for associative interactions between neural events (associative plasticity) (6). Basically, any recent neural synaptic activity will affect the ongoing activity. For example, if synaptic activity is preconditioned by applying tDCS, the application of continuous tDCS after an interval will modulate polarity which will affect performance (6). Continuous anodal tDCS has shown to facilitate performances while consecutive sessions of cathodal tDCS have shown to enhance working memory (81). Preconditioning neural networks may induce synaptic homeostatic changes that seems to be related to compensatory upregulation at post-synaptic membrane receptors due to inhibition $(104,105)$. This has been called as the "rebound effect" where neurons are more excitable due to initial downregulation induced by cathodal tDCS and reversed by conditioning cathodal tDCS (13).

Aberrant plasticity induced by non-invasive brain stimulation techniques has been demonstrated in many neurological and neuropsychiatric disorders including PD (106-108), dystonia (109, 110), multiple sclerosis (111), ischemic stroke (112), migraine (113), AD (114), schizophrenia (115-117), and drug addiction $(103,118)$. 
Regarding tACS, both online and offline effects have reported to generate entertainment and neuroplasticity (45). Entertainment is where external rhythmic pattern imposes itself on the intrinsic natural pattern. Neuroplastic changes have been reported via LTP and LTD as tACS modulates neural synchronization by increasing or decreasing it (45). In summary, tES-induced mechanisms of synaptic plasticity cover different aspects of the neurobiology and neurophysiology of CNS, ranging from gene and protein expression, modulation of neurotrophins activity, and neural transmission and, finally, metaplasticity.

\section{Effects on Neuronal Networks and Connectivity}

Polarization of the brain tissue can extend beyond the area under the electrodes (119-121) and it may have a functional effect also on distant interconnected neural networks (122, 123). Anodal tDCS of the premotor cortex, for example, increases the excitability of the ipsilateral motor cortex (124) and stimulation of the primary motor cortex has inhibitory effects on contralateral motor areas (125). EEG studies support these findings, showing that stimulation of frontal areas induces all-brain synchronous changes of the oscillatory activity (126, 127). Altered prefrontal oscillations and brain synchronization have been reported by magnetoencephalography (MEG) and EEG study in $\mathrm{AD}$, showing functional disconnection between prefrontal cortex and hippocampus and changes of network connectivity (128-130).

Functional connectivity of cortical networks increased within motor, premotor, and somatosensory areas after anodal tDCS, inducing significant intra and interhemispheric connectivity changes, as revealed by analysis of EEG frequency bands (131).

Brain areas interact mutually creating a complex network that underlie higher brain functions and neural synchronization represents an essential system to coordinate cortico-cortical and cortico-subcortical areas $(132,133)$. A combined tDCSfMRI study revealed that after active stimulation functional connectivity showed an increased synchrony in the anticorrelated network (that includes DLPFC) and reduced in the default mode network (DMN) components, thus suggesting a functional reconfiguration of intrinsic brain networks after tDCS (134). This could represent a putative mechanism for tDCSinduced improvement of cognitive functions (134). In addition, using fMRI, anodal tDCS was also shown to modulate functional connectivity of cortical (70), cortico-striatal and thalamo-cortical motor pathway (135). To better grasp the precision of tES, stochastic resonance should be underlined. The concept of stochastic resonance attempts to highlight the importance of wide range of affects due to TES. The electric field can be considered as noise and when added to non-linear systems may enhance or disrupt the state of signal and the noise introduced (136-138). Since the after-effects are not focal but global, the dynamic interactions will modulate not only particular group of neurons but also induce global effects thus affecting neurons near their discharge threshold, thus facilitating or inhibiting a
TABLE 4 | tES after-effects on neuronal networks and connectivity.

\begin{tabular}{|c|c|c|c|}
\hline References/Study & $\begin{array}{l}\text { Methodology } \\
\text { tES }\end{array}$ & Targets & Main results \\
\hline $\begin{array}{l}\text { Boros et al. (124); } \\
\text { Vines et al. (125) }\end{array}$ & $\begin{array}{l}\text { tDCS } \\
-\quad \mathrm{aDCS}\end{array}$ & Motor cortex & $\begin{array}{l}\text { aDCS of premotor } \\
\text { cortex increases the } \\
\text { excitability in ipsilateral } \\
\text { motor cortex. } \\
\text { Stimulation of primary } \\
\text { motor cortex has } \\
\text { inhibitory effect on } \\
\text { contralateral motor } \\
\text { area }\end{array}$ \\
\hline Polanía et al. (131) & tDCS & $\begin{array}{l}\text { Motor/premotor/ } \\
\text { somatosensory } \\
\text { areas }\end{array}$ & $\begin{array}{l}\text { Functional connectivity } \\
\text { of cortical networks } \\
\text { increased with aDCS } \\
\text { with } \\
\text { intra/interhemispheric } \\
\text { connectivity changes }\end{array}$ \\
\hline $\begin{array}{l}\text { Peña-Gómez et al. } \\
\text { (134) }\end{array}$ & tDCS & $\begin{array}{l}\text { Default mode } \\
\text { network and } \\
\text { DLPFC }\end{array}$ & $\begin{array}{l}\text { tDCS increased } \\
\text { synchrony in } \\
\text { anti-correlated network } \\
\text { and reduced in default } \\
\text { mode network }\end{array}$ \\
\hline Stagg et al. (55) & tDCS & $\begin{array}{l}\text { Cortical/cortico- } \\
\text { striatal/thalamo- } \\
\text { cortical motor } \\
\text { pathways }\end{array}$ & $\begin{array}{l}\text { tDCS modulates } \\
\text { functional connectivity } \\
\text { of cortical, } \\
\text { cortico-striatal and } \\
\text { thalamo-cortical motor } \\
\text { pathways }\end{array}$ \\
\hline $\begin{array}{l}\text { Fertonani and } \\
\text { Miniussi (138) }\end{array}$ & tACS/tDCS & - & $\begin{array}{l}\text { tES induces stochastic } \\
\text { resonance which } \\
\text { affects neuronal groups } \\
\text { and induces wide } \\
\text { range of global effects } \\
\text { by facilitating or } \\
\text { inhibiting a } \\
\text { subthreshold signal }\end{array}$ \\
\hline
\end{tabular}

tES, transcranial electrical stimulation; tDCS, transcranial direct current stimulation; tACS, transcranial alternating current stimulation; a/c tDCS, anodal/cathodal transcranial direct current stimulation; DLPFC, dorsolateral prefrontal cortex.

subthreshold signal which will produce two different polarized after effects (138).

See Table 4 for a summary of the main tES studies and results on neuronal networks and connectivity.

\section{Effects on Glial Cells and Neuroinflammation}

The relevance of glial biology cannot be neglected to understand the complexity of the CNS and the comprehensive mechanisms and effects of tES. The significance is clinically appealing as glial cells create a wide neuro-glial network for rapid intercellular long-range signaling (73) and are early affected in many CNS disorders. Although the glial cells have attracted limited interest for decades, it is only recently that studies have focused on their role in maintaining synaptic homeostasis and modulating synaptic plasticity in health and disease (139). Astrocytes and microglial cells are in close proximity with synapses as they directly modulate synapse formation and 
elimination (140). The loss of integrity of these supportive cells is the trigger of neurodegenerative disorders (141-143). Initially it was believed that $\mathrm{AD}$ was consequentially due to $\mathrm{A} \beta$ oligomers and fibrils that accumulate and inflammation. However, now it has been demonstrated that glial cells drive the synaptic loss in AD (144-147). In addition, glial mediated synapse formation may impair synaptic turnover and homeostasis which disrupts synaptic plasticity. Reactive gliosis is a process of hypertrophy and proliferation of glial cells in response to an insult such infection/trauma/neurodegenerative disorders $(140,148)$. This is proceeded by release of chemokines, cytokines and neurotrophic factors that have both neuroprotective (M2-like microglia) and neuroinflammatory effect (M1-like microglia) (84). This leads to a simultaneous process of neural damage and synaptic loss with tissue remodeling and phagocytosis.

To our best knowledge, there are no reports regarding the activity of tACS on glial cells. Significant after-effects of tDCS on glial cells function and plasticity are reported by several groups in the last years (see Table 5). This is supported by the fact that astrocytes possess voltage-gated channels and transporters that are sensitive to changes of membrane potential $(152,153)$. Administration of tDCS has shown to cause a surge in $\mathrm{Ca}^{2+}$ in cortical astrocytes that is correlated to an overexpression of the glutamate NMDA receptor (154). Evidence suggests that $\mathrm{tES}$ modulates the activity of microglia cells but also the neuroinflammatory response, triggering both pro-inflammatory and anti-inflammatory reaction (149). Cathodal and anodal tDCS produce microglial activation as indicated by the increase of Iba-1, an immunostaining marker of activated microglia (150). High voltage anodal and cathodal tDCS was demonstrated to trigger an inflammatory response in the microglial cell line BV2, showing increase of cyclooxygenase 2 (COX-2) expression, leukocyte transmigration through blood brain barrier $(32,149)$. On the other hand, there was decrease of tumor necrosis factoralpha (TNF- $\alpha)$ in rat hippocampus after anodal tDCS of parietal cortex (151). Modulation of the neuroinflammatory reaction is relevant because microglia activation can be beneficial as well as detrimental for neural tissue depending on the time of activation. This is clinically relevant in the case of ischemic stroke, because tDCS can activate innate immune response and attract neural stem cells. In vitro experiments suggest that cathodal tDCS, delivered for 5 days, can induce cell proliferation and attract neural crest stem cells (149), forming a reservoir of neurotrophic factors which improved functional recovery. In addition, tDCS has also been shown to influence astrocytes by aligning them perpendicular to the electrical field in both vitro and in vivo (155-157).

Due to the remarkable connectivity of astrocytes and their pivotal role in neuronal connectivity, non-invasive brain modulation may have profound neurobiological effects (158).

\section{POTENTIAL CLINICAL APPLICATIONS OF CURRENT STIMULATION}

Efficacy of tES in the clinical setting has been supported by many experimental works and clinical reports that has demonstrated
TABLE 5 | tES after-effects on glial cells and inflammation.

\begin{tabular}{|c|c|c|c|}
\hline References/Study & $\begin{array}{l}\text { Methodology } \\
\text { tES }\end{array}$ & Targets & Main results \\
\hline Rueger et al. (149) & DCS & $\begin{array}{l}\text { Microglial } \\
\text { cells }\end{array}$ & $\begin{array}{l}\text { tES produces both } \\
\text { proinflammatory and } \\
\text { anti-inflammatory } \\
\text { reactions }\end{array}$ \\
\hline $\begin{array}{l}\text { Pikhovych et al. } \\
\text { (150) }\end{array}$ & $\begin{array}{l}\text { tDCS } \\
-\mathrm{cDCS} \\
-\mathrm{aDCS}\end{array}$ & $\begin{array}{l}\text { Microglial } \\
\text { cells and } \\
\text { lba-1 }\end{array}$ & $\begin{array}{l}\text { CDCS and aDCS cause } \\
\text { microglial activation } \\
\text { with increase in lba-1 } \\
\text { markers }\end{array}$ \\
\hline $\begin{array}{l}\text { Rueger et al. (149); } \\
\text { Pelletier and } \\
\text { Cicchetti (32) }\end{array}$ & $\begin{array}{l}\text { High voltage } \\
\text { DCS } \\
\text { - cDCS } \\
\text { - aDCS }\end{array}$ & $\begin{array}{l}\text { Microglial cell } \\
\text { BV2 }\end{array}$ & $\begin{array}{l}\text { High voltage aDCS and } \\
\text { cDCS induces } \\
\text { activation of microglial } \\
\text { cells BV2 with } \\
\text { increased expression of } \\
\text { cOX-2 } \\
\text { (cyclooxygenase 2) and } \\
\text { leukocyte } \\
\text { transmigration }\end{array}$ \\
\hline $\begin{array}{l}\text { Spezia Adachi } \\
\text { et al. (151) }\end{array}$ & $\begin{array}{l}\text { DCS } \\
- \text { aDCS }\end{array}$ & $\begin{array}{l}\text { Hippocampal } \\
\text { neurons }\end{array}$ & $\begin{array}{l}\text { aDCS of parietal cortex } \\
\text { decreased tumor } \\
\text { necrosis factor alfa } \\
(\mathrm{TNF}-\alpha) \text { in the rat } \\
\text { hippocampus }\end{array}$ \\
\hline Rueger et al. (149) & DCS & $\begin{array}{l}\text { Neural crest } \\
\text { stem cells }\end{array}$ & $\begin{array}{l}\text { 5-day cDCS induced } \\
\text { cell proliferation and } \\
\text { attracted neural stem } \\
\text { cells }\end{array}$ \\
\hline
\end{tabular}

tES, transcranial electrical stimulation; DCS, direct current stimulation; a/c DCS, anodal/cathodal direct current stimulation.

a long-lasting efficacy in many neurological and psychiatric conditions (5). Despite neurobiological mechanisms have not been yet fully understood, it is supposed that tES-induced modulation of cortical excitability through changes in cell firing rate could pave the way for future therapeutic applications (159).

Application of tACS in the clinical setting is very limited and largely implemented in the psychiatric settings $(160,161)$. Accordingly, tACS was shown to successfully manipulate auditory hallucinations in schizophrenia by decoupling interhemispheric connectivity and, when administered to schizophrenic patients to the left dorsolateral prefrontal cortex and posterior parietal region in theta frequency $(6 \mathrm{~Hz})$, improved working memory tasks (162). Moreover, $40 \mathrm{~Hz}$ tACS induced improvement/remission of symptoms in major depression (163) and obsessive compulsive disorder (164) by modulation of EEG-gamma frequency bands. Enhancement of gamma band power connectivity by tACS was also effective in patients with $\mathrm{AD}$ and mild cognitive impairment $(165,166)$.

Experimental and clinical research with tDCS has been widely explored for its ability to suppress neuronal hyperexcitability or by enhancing inhibition (167). While cathodal tDCS reduces cortical excitability due to neuronal hyperpolarization, anodal tDCS causes an increase in cortical excitability and promotes neuronal depolarization (168). These neurobiological effects might be the substrate to counteract the temporoparietal hypoactivity (atrophy, reduced metabolic rate, and perfusion) 
reported in $\mathrm{AD}$, suggesting an innovative therapeutic strategy (169).

In an experimental rat model of stroke, tDCS induced a dramatic increase in spine density of cortical neurons at the site of infarct, indicating that it may promote neural plasticity after stroke (170). Accordingly, tDCS was found to down-regulate the elevated hemichannel pannexin-1 mRNA expression after brain ischemia (thus reducing membrane permeability), but also increase the expression of MAP-2 and GAP-43 proteins, allowing axons to regrow at the infarcted site through the glial scar and redevelop their functions (171). Interestingly, tDCS performed within 3 days after stroke did not improve motor function, in contrast when performed 7-14 days after stroke resulted in more pronounced motor function improvement, thus identifying an optimal time-window for tDCS therapy after stroke (171).

In patients with multiple sclerosis (MS) that received tDCS, MRI detected (1) increased cerebral metabolic rate of oxygen $\left(\mathrm{CMRO}_{2}\right)$, an indicator of the overall brain/neural activity, and (2) a reduced neuronal reactivity (172).

Seizures are described as a result of an increased excitability and inefficient inhibitory control in foci with altered neuronal homeostasis $(72,173,174)$. In the recent years, many works have reported the efficacy of tES in the treatment of drugresistant seizures. Authors observed an enhanced neuronal plasticity and synaptic reorganization after tES (100). For example, it has been reported that temporal lobe epilepsy responded to tES of hippocampus (101) and low frequency tACS applied over the epileptic foci might reduce interictal and ictal activities in epileptics (175). Moreover, experimental evidence in a rat model of focal epilepsy demonstrated that cathodal tDCS has an anticonvulsant effect through increase of the localized seizure threshold that outlasted the stimulation (176). Similar results were confirmed on a refractory pediatric epileptic patient with focal cortical dysplasia who was treated with cathodal tDCS and experienced marked reduction in the frequency of seizures (177). Along with this, cathodal tDCS was reported to prevent the loss of GABAergic inhibition, which provokes seizures after pentylenetetrazol administration, thus proposing a new antiepileptic mechanism (178). These results, therefore, have posed the basis to the clinical combination of the cathodal tDCS with GABA-agonist antiepileptic drugs (AEDs), such as benzodiazepines, valproic acid, felbamate, topiramate, and barbiturates, in order to increase the antiepileptic stimulation effect.

Application of tDCS is not limited to the cerebral cortex and its disorders but also for the modulation of the excitability in the cerebellum and spinal cord. Since pharmacological approaches to treat cerebellar diseases are still lacking, tES might represent a new potential therapeutic approach that is yet to be explored. The mechanisms behind the neurophysiological effects of tDCS applied over cerebellum have not been extensively researched as compared to cerebral cortex. However, it could be inferred that ionic gradient shifts, cellular activation and inhibition, modulation of neurotransmission may occur in the same way (179). Evidence suggests that cerebellar cathodal tDCS decreases the inhibitory tone of cerebellum on primary motor cortex while anodal tDCS increases it, likely through a specific modulation of dentate-thalamo-cortical connections (21). TDCS also modulates cerebellum-dependent motor learning: anodal tDCS improved the performance in a locomotor adaptation task (180). Mechanisms need to be further explored, however it has been hypothesized that anodal tDCS may broaden the availability of Purkinje cells for learning or increase the dynamic range of these cells, whereas cathodal tDCS may reduce the excitability of Purkinje cells (181). The effects of tDCS on cerebellomotor connectivity were studied in 20 patients with ataxia with administration of cerebello-spinal tDCS (179). Improvement in ataxia was reported and was associated with restoration of motor cortex excitability and cerebellar-brain inhibition.

Application of spinal tDCS is very limited but the preliminary results are extremely interesting. It has been reported that spinal anodal tDCS reduces the amplitude of laser evoked potentials of stimulated A $\delta$ fibers (182) and increases cortico-spinal excitability in a polarity-independent manner (183). While spinal anodal tDCS inhibits the ascending pathways and enhances the reflex circuitry, the spinal cathodal tDCS enhances the activity of ascending pathways and suppresses the reflex circuitry in humans (181). Since there is involvement of the ascending and descending pathways, the glutamatergic, GABAergic and glycinergic systems should be involved in modulating the spinal plasticity (181). The effects of this kind of stimulation can vary in response to several factors including intensity, polarity and direction (184) but also through modulation of the voltage-gated $\mathrm{Ca}^{2+}$ channels in the spinal motor neuron dendrites (185). Altogether, these preliminary results demonstrate the ability to modulate spinal plasticity with electrical current stimulation, paving the way for new therapeutic strategies in neurological disorders with impaired spinal excitability.

\section{CHALLENGES AND FUTURE DIRECTIONS}

To date, despite the undisputed role of tES in experimental settings in humans as a tool to "switch on/off" specific brain regions that are supposed to be involved in several higher brain functions, its translation into clinical settings is still far to be reached due to the difficulty in producing clinically significant effects in the majority of subjects/patients. This is largely due to the lack of a full comprehension of both the neurobiological bases of tES and the specific neuropathological mechanisms of disease. There are still few data on the possible clinical efficacy of prolonged/repeated protocols of stimulation that might produce persistent changes in synaptic efficacy that cannot be achieved by a short-lasting intervention. In this context, successful trials of prolonged tES protocols could eventually be translated into invasive implants of cortical electrodes for chronic stimulation. Finally, tDCS shows lack of selectivity that might influence different cortical circuits and produce side effects that counteract the effects responsible for the therapeutic action. Therefore, optimizing protocols, electrode size and intensity of stimulation should help to overcome these technical limitations that impedes a tailored approach to the patient and disease. 


\section{AUTHOR CONTRIBUTIONS}

SK: acquisition, analysis, and interpretation of data for the work and drafting the manuscript. FR: supervising and editing the manuscript and final approval of the manuscript to be submitted. VD: conception and design of the work, supervising and editing the manuscript, and final approval of the manuscript to be submitted. MP: critical supervision, manuscript editing, and final approval of the draft to be submitted. GC: conception and design of the work, analysis and interpretation of data, revising

\section{REFERENCES}

1. Schlaug G, Renga V, Nair D. Transcranial direct current stimulation in stroke recovery. Arch Neurol. (2008) 65:1571-6. doi: 10.1001/archneur.65.12.1571

2. Nitsche MA, Paulus W. Noninvasive brain stimulation protocols in the treatment of epilepsy: current state and perspectives. Neurotherapeutics. (2009) 6:244-50. doi: 10.1016/j.nurt.2009.01.003

3. VanHaerents S, Chang BS, Rotenberg A, Pascual-Leone A, Shafi MM. Noninvasive brain stimulation in epilepsy. J Clin Neurophysiol. (2020) 37:118-30. doi: 10.1097/WNP.0000000000000573

4. Wu AD, Fregni F, Simon DK, Deblieck C, Pascual-Leone A. Noninvasive Brain stimulation for Parkinson's disease and dystonia. Neurotherapeutics. (2008) 5:345-61. doi: 10.1016/j.nurt.2008.02.002

5. Lefaucheur JP, Antal A, Ayache SS, Benninger DH, Brunelin J, Cogiamanian F, et al. Evidence-based guidelines on the therapeutic use of transcranial direct current stimulation (tDCS). Clin Neurophysiol. (2017) 128:5692. doi: 10.1016/j.clinph.2016.10.087

6. Hurley R, Machado L. Using tDCS priming to improve brain function: can metaplasticity provide the key to boosting outcomes? Neurosci Biobehav Rev. (2017) 83:155-9. doi: 10.1016/j.neubiorev.2017.09.029

7. Matsumoto H, Ugawa Y. Adverse events of tDCS and tACS: A review. Clin Neurophysiol Pract. (2017) 2:19-25. doi: 10.1016/j.cnp.2016.12.003

8. Ritaccio AL, Brunner P, Schalk G. Electrical stimulation mapping of the brain: basic principles and emerging alternatives. J Clin Neurophysiol. (2018) 35:86-97. doi: 10.1097/WNP.0000000000000440

9. Priori A. Brain polarization in humans: a reappraisal of an old tool for prolonged non-invasive modulation of brain excitability. Clin Neurophysiol. (2003) 114:589-95. doi: 10.1016/S1388-2457(02)00437-6

10. Zago S, Ferrucci R, Fregni F, Priori A. Bartholow, sciamanna, alberti: pioneers in the electrical stimulation of the exposed human cerebral cortex. Neuroscientist. (2008) 14:521-8. doi: 10.1177/10738584073 11101

11. Bindman LJ, Lippold OCJ, Redfearn JWT. Long-lasting changes in the level of the electrical activity of the cerebral cortex produced by polarizing currents. Nature. (1962) 196:584-5. doi: 10.1038/196584a0

12. Bindman LJ, Lippold OCJ, Redfearn JWT. The action of brief polarizing currents on the cerebral cortex of the rat (1) during flow and (2) in the production of long-lasting effects. J Physiol. (1964) 172:36982. doi: 10.1113/jphysiol.1964.sp007425

13. Creutzfeldt OD, Fromm GH, Kapp H. Influence of transcortical dc currents on cortical neuronal activity. Exp Neurol. (1962) 5:43652. doi: 10.1016/0014-4886(62)90056-0

14. Purpura DP, McMurtry JG. Intracellular activities and evoked potential changes during polarization of motor cortex. J Neurophysiol. (1965) 28:16685. doi: 10.1152/jn.1965.28.1.166

15. Nitsche MA, Paulus W. Sustained excitability elevations induced by transcranial DC motor cortex stimulation in humans. Neurology. (2001) 57:1899-901. doi: 10.1212/WNL.57.10.1899

16. Lang N, Nitsche MA, Paulus W, Rothwell JC, Lemon RN. Effects of transcranial direct current stimulation over the human motor cortex on corticospinal and transcallosal excitability. Exp Brain Res. (2004) 156:43943. doi: $10.1007 / \mathrm{s} 00221-003-1800-2$ the manuscript, and final approval of the manuscript to be submitted. All authors contributed to the article and approved the submitted version.

\section{FUNDING}

This work was supported by grants from the Italian Minister of University and Research (MUR) (PRIN2017-2017XJ38A4_003to GC and MP).

17. Lang N, Nitsche MA, Dileone M, Mazzone P, Andrès-Arès J, Diaz-Jara L, et al. Transcranial direct current stimulation effects on I-wave activity in humans. J Neurophysiol. (2011) 105:2802-10. doi: 10.1152/jn.00617.2010

18. Islam N, Aftabuddin M, Moriwaki A, Hattori Y, Hori Y. Increase in the calcium level following anodal polarization in the rat brain. Brain Res. (1995) 684:206-8. doi: 10.1016/0006-8993(95)00434-R

19. Liebetanz D. Pharmacological approach to the mechanisms of transcranial DC-stimulation-induced after-effects of human motor cortex excitability. Brain. (2002) 125:2238-47. doi: 10.1093/brain/awf238

20. Ranieri F, Podda MV, Riccardi E, Frisullo G, Dileone M, Profice P, et al. Modulation of LTP at rat hippocampal CA3-CA1 synapses by direct current stimulation. J Neurophysiol. (2012) 107:1868-80. doi: 10.1152/jn.00319.2011

21. Fritsch B, Reis J, Martinowich K, Schambra HM, Ji Y, Cohen LG, et al. Direct current stimulation promotes BDNF-dependent synaptic plasticity: potential implications for motor learning. Neuron. (2010) 66:198204. doi: 10.1016/j.neuron.2010.03.035

22. Albensi BC, Oliver DR, Toupin J, Odero G. Electrical stimulation protocols for hippocampal synaptic plasticity and neuronal hyperexcitability: are they effective or relevant? Exp Neurol. (2007) 204:113. doi: 10.1016/j.expneurol.2006.12.009

23. Polanía R, Nitsche MA, Ruff CC. Studying and modifying brain function with non-invasive brain stimulation. Nat Neurosci. (2018) 21:17487. doi: 10.1038/s41593-017-0054-4

24. Cooper LN, Bear MF. The BCM theory of synapse modification at 30: Interaction of theory with experiment. Nat Rev Neurosci. (2012) 13:798810. doi: 10.1038/nrn3353

25. Yu TH, Wu YJ, Chien ME, Hsu KS. Transcranial direct current stimulation induces hippocampal metaplasticity mediated by brain-derived neurotrophic factor. Neuropharmacology. (2019) 144:358-67. doi: 10.1016/j.neuropharm.2018.11.012

26. Di Lazzaro V, Manganelli F, Dileone M, Notturno F, Esposito M, Capasso M, et al. The effects of prolonged cathodal direct current stimulation on the excitatory and inhibitory circuits of the ipsilateral and contralateral motor cortex. J Neural Transm. (2012) 119:1499506. doi: 10.1007/s00702-012-0845-4

27. Moliadze V, Antal A, Paulus W. Boosting brain excitability by transcranial high frequency stimulation in the ripple range. J Physiol. (2010) 588:4891904. doi: 10.1113/jphysiol.2010.196998

28. Strüber H, Rach S, Neuling T, Herrmann C. On the possible role of stimulation duration for after-effects of transcranial alternating current stimulation. Front Cell Neurosci. (2015) 9:311. doi: 10.3389/fncel.2015.00311

29. Kasten FH, Dowsett J, Herrmann CS. Sustained aftereffect of $\alpha$-tACS lasts Up to $70 \mathrm{~min}$ after stimulation. Front Hum Neurosci. (2016) 10:245 doi: 10.3389 /fnhum 2016.00245

30. Battleday RM, Muller T, Clayton MS, Cohen Kadosh R. Mapping the mechanisms of transcranial alternating current stimulation: a pathway from network effects to cognition. Front Psychiatry. (2014) 5:162. doi: 10.3389/fpsyt.2014.00162

31. Guerra A, Ranieri F, Falato E, Musumeci G, Di Santo A, Asci F, et al. Detecting cortical circuits resonant to high-frequency oscillations in the human primary motor cortex: a TMS-tACS study. Sci Rep. (2020) 10:7695. doi: 10.1038/s41598-020-64717-7 
32. Pelletier SJ, Cicchetti F. Cellular and molecular mechanisms of action of transcranial direct current stimulation: evidence from in vitro and in vivo models. Int J Neuropsychopharmacol. (2015) 18:1-13. doi: 10.1093/ijnp/pyu047

33. Zaghi S, Acar M, Hultgren B, Boggio PS, Fregni F. Noninvasive brain stimulation with low-intensity electrical currents: putative mechanisms of action for direct and alternating current stimulation. Neuroscientist. (2010) 16:285-307. doi: 10.1177/1073858409336227

34. Rostami M, Golesorkhi M, Ekhtiari H. Methodological dimensions of transcranial brain stimulation with the electrical current in human. Basic Clin Neurosci. (2013) 4:8-26.

35. Priori A, Hallett M, Rothwell JC. Repetitive transcranial magnetic stimulation or transcranial direct current stimulation? Brain Stimul. (2009) 2:241-5. doi: 10.1016/j.brs.2009.02.004

36. Nitsche MA, Cohen LG, Wassermann EM, Priori A, Lang N, Antal A, et al. Transcranial direct current stimulation: state of the art 2008. Brain Stimul. (2008) 1:206-23. doi: 10.1016/j.brs.2008.06.004

37. Nitsche MA, Kuo M-F, Paulus W, Antal A. Transcranial direct current stimulation: protocols and physiological mechanisms of action. In: Textbook of Neuromodulation. New York, NY: Springer. (2014). p. 10111. doi: 10.1007/978-1-4939-1408-1_9

38. Paulus W. Transcranial electrical stimulation (tES - tDCS; tRNS, tACS) methods. Neuropsychol Rehabil. (2011) 21:60217. doi: 10.1080/09602011.2011.557292

39. Antal A, Paulus W. Transcranial alternating current stimulation (tACS). Front Hum Neurosci. (2013) 7:317. doi: 10.3389/fnhum.2013.00317

40. Vosskuhl J, Strüber D, Herrmann CS. Non-invasive brain stimulation: a paradigm shift in understanding brain oscillations. Front Hum Neurosci. (2018) 12:211. doi: 10.3389/fnhum.2018.00211

41. Thut G, Schyns PG, Gross J. Entrainment of perceptually relevant brain oscillations by non-invasive rhythmic stimulation of the human brain. Front Psychol. (2011) 2:170. doi: 10.3389/fpsyg.2011.00170

42. Tavakoli AV, Yun K. Transcranial alternating current stimulation (tACS) mechanisms and protocols. Front Cell Neurosci. (2017) 11:214. doi: 10.3389/fncel.2017.00214

43. Liu A, Vöröslakos M, Kronberg G, Henin S, Krause MR, Huang Y, et al. Immediate neurophysiological effects of transcranial electrical stimulation. Nat Commun. (2018) 9:5092. doi: 10.1038/s41467-018-07233-7

44. Elyamany O, Leicht G, Herrmann CS, Mulert C. Transcranial alternating current stimulation (tACS): from basic mechanisms towards first applications in psychiatry. Eur Arch Psychiatry Clin Neurosci. (2020) doi: 10.1007/s00406-020-01209-9

45. Zaehle T, Rach S, Herrmann CS. Transcranial alternating current stimulation enhances individual alpha activity in human EEG. PLoS ONE. (2010) 5:e13766. doi: 10.1371/journal.pone.0013766

46. Guerra A, Suppa A, Bologna M, D’Onofrio V, Bianchini E, Brown P, et al. Boosting the LTP-like plasticity effect of intermittent theta-burst stimulation using gamma transcranial alternating current stimulation. Brain Stimul. (2018) 11:734-42. doi: 10.1016/j.brs.2018.03.015

47. Wischnewski M, Engelhardt M, Salehinejad MA, Schutter DJLG, Kuo MF, Nitsche MA. NMDA receptor-mediated motor cortex plasticity after $20 \mathrm{~Hz}$ transcranial alternating current stimulation. Cereb Cortex. (2019) 29:292431. doi: 10.1093/cercor/bhy160

48. Hopfinger JB, Parsons J, Fröhlich F. Differential effects of $10-\mathrm{Hz}$ and $40-\mathrm{Hz}$ transcranial alternating current stimulation (tACS) on endogenous versus exogenous attention. Cogn Neurosci. (2017) 8:102-11. doi: $10.1080 / 17588928.2016 .1194261$

49. Hallett M. Transcranial magnetic stimulation: a primer. Neuron. (2007) 55:187-99. doi: 10.1016/j.neuron.2007.06.026

50. Cirillo G, Di Pino G, Capone F, Ranieri F, Florio L, Todisco V, et al. Neurobiological after-effects of non-invasive brain stimulation. Brain Stimul. (2017) 10:1-18. doi: 10.1016/j.brs.2016.11.009

51. Pascual-Leone A, Grafman J, Hallett M. Modulation of cortical motor output maps during development of implicit and explicit knowledge. Science. (1994) 263:1287-9. doi: 10.1126/science.8122113

52. Suppa A, Huang Y-Z, Funke K, Ridding MC, Cheeran B, Di Lazzaro V, et al. Ten years of theta burst stimulation in humans: established knowledge, unknowns and prospects. Brain Stimul. (2016) 9:323-35. doi: 10.1016/j.brs.2016.01.006
53. Terao Y, Ugawa Y. Basic mechanisms of TMS. J Clin Neurophysiol. (2002) 19:322-43. doi: 10.1097/00004691-200208000-00006

54. Peterchev AV, Wagner TA, Miranda PC, Nitsche MA, Paulus W, Lisanby $\mathrm{SH}$, et al. Fundamentals of transcranial electric and magnetic stimulation dose: definition, selection, and reporting practices. Brain Stimul. (2012) 5:435-53. doi: 10.1016/j.brs.2011.10.001

55. Stagg CJ, Nitsche MA. Physiological basis of transcranial direct current stimulation. Neuroscientist. (2011) 17:3753. doi: $10.1177 / 1073858410386614$

56. Bikson $M$, Inoue $M$, Akiyama $H$, Deans $J K$, Fox JE, Miyakawa $\mathrm{H}$, et al. Effect of uniform extracellular DC electric fields on excitability in rat hippocampal slices in vitro. J Physiol. (2004) 557:175-90. doi: 10.1113/jphysiol.2003.055772

57. Arlotti M, Rahman A, Minhas P, Bikson M. Axon terminal polarization induced by weak uniform DC electric fields: a modeling study. Annu Int Conf IEEE Eng Med Biol Soc. (2012) 2012:4575-8. doi: 10.1109/EMBC.2012.6346985

58. Rahman A, Reato D, Arlotti M, Gasca F, Datta A, Parra LC, et al. Cellular effects of acute direct current stimulation: somatic and synaptic terminal effects. J Physiol. (2013) 591:2563-78. doi: 10.1113/jphysiol.2012.247171

59. Seo H, Jun SC. Relation between the electric field and activation of cortical neurons in transcranial electrical stimulation. Brain Stimul. (2019) 12:27589. doi: $10.1016 /$ j.brs.2018.11.004

60. Francis JT, Gluckman BJ, Schiff SJ. Sensitivity of neurons to weak electric fields. $J$ Neurosci. (2003) 23:725561. doi: 10.1523/JNEUROSCI.23-19-07255.2003

61. Deans JK, Powell AD, Jefferys JGR. Sensitivity of coherent oscillations in rat hippocampus to AC electric fields. J Physiol. (2007) 583:55565. doi: 10.1113/jphysiol.2007.137711

62. Reato D, Rahman A, Bikson M, Parra LC. Low-intensity electrical stimulation affects network dynamics by modulating population rate and spike timing. J Neurosci. (2010) 30:1506779. doi: 10.1523/JNEUROSCI.2059-10.2010

63. Antal A, Herrmann CS. Transcranial alternating current and random noise stimulation: possible mechanisms. Neural Plast. (2016) 2016:112. doi: $10.1155 / 2016 / 3616807$

64. Lisman JE. Three $\mathrm{Ca} 2+$ levels affect plasticity differently: the LTP zone, the LTD zone and no man's land. J Physiol. (2001) 532:285. doi: 10.1111/j.1469-7793.2001.0285f.x

65. Kirsch DL, Nichols F. Cranial electrotherapy stimulation for treatment of anxiety, depression, and insomnia. Psychiatr Clin North Am. (2013) 36:16976. doi: $10.1016 /$ j.psc.2013.01.006

66. Kirsch D. The Science Behind Cranial Electrotherapy Stimulation. 2nd Ed. Alberta: Medical Scope Publishing Corporation (2002).

67. Limoge A, Robert C, Stanley TH. Transcutaneous cranial electrical stimulation (TCES): a review 1998. Neurosci Biobehav Rev. (1999) 23:52938. doi: 10.1016/S0149-7634(98)00048-7

68. Nitsche MA, Boggio PS, Fregni F, Pascual-Leone A. Treatment of depression with transcranial direct current stimulation (tDCS): a review. Exp Neurol. (2009) 219:14-9. doi: 10.1016/j.expneurol.2009.03.038

69. Zhao X, Ding J, Pan H, Zhang S, Pan D, Yu H, et al. Anodal and cathodal tDCS modulate neural activity and selectively affect GABA and glutamate syntheses in the visual cortex of cats. J Physiol. (2020) 598:372745. doi: 10.1113/JP279340

70. Stagg CJ, O'Shea J, Kincses ZT, Woolrich M, Matthews PM, JohansenBerg H. Modulation of movement-associated cortical activation by transcranial direct current stimulation. Eur J Neurosci. (2009) 30:141223. doi: 10.1111/j.1460-9568.2009.06937.x

71. Hansen N. Action mechanisms of transcranial direct current stimulation in Alzheimer's disease and memory loss. Front Psychiatry. (2012) 3:48. doi: 10.3389/fpsyt.2012.00048

72. Nitsche M, Liebetanz D, Schlitterlau A, Henschke U, Fricke K, Frommann $\mathrm{K}$, et al. GABAergic modulation of DC stimulation-induced motor cortex excitability shifts in humans. Eur J Neurosci. (2004) 19:27206. doi: 10.1111/j.0953-816X.2004.03398.x

73. Malenka RC, Bear MF. LTP and LTD: an embarrassment of riches. Neuron. (2004) 44:5-21. doi: 10.1016/j.neuron.2004.09.012

74. Cooke SF, Bliss TVP. Plasticity in the human central nervous system. Brain. (2006) 129:1659-73. doi: 10.1093/brain/awl082 
75. Lanté F, de Jésus Ferreira M-C, Guiramand J, Récasens M, Vignes M. Low-frequency stimulation induces a new form of LTP, metabotropic glutamate (mGlu5) receptor- and PKA-dependent, in the CA1 area of the rat hippocampus. Hippocampus. (2006) 16:345-60. doi: 10.1002/hipo. 20146

76. Luscher C, Malenka RC. NMDA receptor-dependent long-term potentiation and long-term depression (LTP/LTD). Cold Spring Harb Perspect Biol. (2012) 4:a005710. doi: 10.1101/cshperspect.a005710

77. Mycielska ME, Djamgoz MBA. Cellular mechanisms of direct-current electric field effects: Galvanotaxis and metastatic disease. J Cell Sci. (2004) 117:1631-9. doi: 10.1242/jcs.01125

78. McCaig CD, Rajnicek AM, Song B, Zhao M. Controlling cell behavior electrically: current views and future potential. Physiol Rev. (2005) 85:94378. doi: 10.1152/physrev.00020.2004

79. Monte-Silva K, Liebetanz D, Grundey J, Paulus W, Nitsche MA. Dosagedependent non-linear effect of l-dopa on human motor cortex plasticity. $J$ Physiol. (2010) 588:3415-24. doi: 10.1113/jphysiol.2010.190181

80. Kuo MF, Paulus W, Nitsche MA. Boosting focally-induced brain plasticity by dopamine. Cereb Cortex. (2008) 18:648-51. doi: 10.1093/cercor/bhm098

81. Carvalho S, Boggio PS, Gonçalves ÓF, Vigário AR, Faria M, Silva S, et al. Transcranial direct current stimulation based metaplasticity protocols in working memory. Brain Stimul. (2015) 8:289-94. doi: 10.1016/j.brs.2014.11.011

82. Cirillo G, Colangelo AM, Bianco MR, Cavaliere C, Zaccaro L, Sarmientos P, et al. BB14, a Nerve Growth Factor (NGF)-like peptide shown to be effective in reducing reactive astrogliosis and restoring synaptic homeostasis in a rat model of peripheral nerve injury. Biotechnol Adv. (2012) 30:22332. doi: 10.1016/j.biotechadv.2011.05.008

83. Pang PT. Cleavage of proBDNF by tPA/Plasmin is essential for long-term hippocampal plasticity. Science. (2004) 306:48791. doi: 10.1126/science.1100135

84. Cirillo G, Bianco MR, Colangelo AM, Cavaliere C, Daniele DL, Zaccaro $\mathrm{L}$, et al. Reactive astrocytosis-induced perturbation of synaptic homeostasis is restored by nerve growth factor. Neurobiol Dis. (2011) 41:6309. doi: 10.1016/j.nbd.2010.11.012

85. Nagappan G, Zaitsev E, Senatorov VV, Yang J, Hempstead BL, Lu B. Control of extracellular cleavage of ProBDNF by high frequency neuronal activity. Proc Natl Acad Sci USA. (2009) 106:1267-72. doi: 10.1073/pnas.0807 322106

86. Grau JW, Russell Huie J, Lee KH, Hoy KC, Huang YJ, Turtle JD, et al. Metaplasticity and behavior: how training and inflammation affect plastic potential within the spinal cord and recovery after injury. Front Neural Circuits. (2014) 8:100. doi: 10.3389/fncir.2014.00100

87. Podda MV, Cocco S, Mastrodonato A, Fusco S, Leone L, Barbati SA, et al. Anodal transcranial direct current stimulation boosts synaptic plasticity and memory in mice via epigenetic regulation of Bdnf expression. Sci Rep. (2016) 6:22180. doi: $10.1038 /$ srep22180

88. Matsuda N, Lu H, Fukata Y, Noritake J, Gao H, Mukherjee S, et al. Differential activity-dependent secretion of brain-derived neurotrophic factor from axon and dendrite. J Neurosci. (2009) 29:14185-98. doi: 10.1523/JNEUROSCI.1863-09.2009

89. Park H, Popescu A, Poo M ming. Essential role of presynaptic NMDA receptors in activity-dependent BDNF secretion corticostriatal LTP. Neuron. (2014) 84:1009-22. doi: 10.1016/j.neuron.2014. 10.045

90. Sumi T, Harada K. Mechanism underlying hippocampal longterm potentiation and depression based on competition between endocytosis and exocytosis of AMPA receptors. Sci Rep. (2020) 10:14711. doi: 10.1038/s41598-020-71528-3

91. Nitsche MA, Paulus W. Transcranial direct current stimulation - Update 2011. Restor Neurol Neurosci. (2011) 29:46392. doi: 10.3233/RNN-2011-0618

92. Thirugnanasambandam N, Paulus W, Kuo M-F, Liebetanz D, MonteSilva K, Nitsche MA. Dose-dependent inverted u-shaped effect of dopamine (D2-Like) receptor activation on focal and nonfocal plasticity in humans. J Neurosci. (2009) 29:6124-31. doi: 10.1523/JNEUROSCI.0728-0 9.2009
93. Pláteník J, Kuramoto N, Yoneda Y. Molecular mechanisms associated with long-term consolidation of the NMDA signals. Life Sci. (2000) 67:33564. doi: 10.1016/S0024-3205(00)00632-9

94. Guzman-Karlsson MC, Meadows JP, Gavin CF, Hablitz JJ, Sweatt JD. Transcriptional and epigenetic regulation of Hebbian and non-Hebbian plasticity. Neuropharmacology. (2014) 80:317. doi: 10.1016/j.neuropharm.2014.01.001

95. Davis S, Bozon B, Laroche S. How necessary is the activation of the immediate early gene zif 268 in synaptic plasticity and learning? Behav Brain Res. (2003) 142:17-30. doi: 10.1016/S0166-4328(02)00421-7

96. Turrigiano GG, Leslie KR, Desai NS, Rutherford LC, Nelson SB. Activitydependent scaling of quantal amplitude in neocortical neurons. Nature. (1998) 391:892-6. doi: 10.1038/36103

97. Latremoliere A, Woolf CJ. Central sensitization: a generator of pain hypersensitivity by central neural plasticity. J Pain. (2009) 10:895926. doi: 10.1016/j.jpain.2009.06.012

98. Davis GW, Bezprozvanny I. Maintaining the stability of neural function: a homeostatic hypothesis. Annu Rev Physiol. (2001) 63:847-69. doi: 10.1146/annurev.physiol.63.1.847

99. Fedorov A, Chibisova Y, Szymaszek A, Alexandrov M, Gall C, Sabel BA. Noninvasive alternating current stimulation induces recovery from stroke. Restor Neurol Neurosci. (2010) 28:825-33. doi: 10.3233/RNN-2010-0580

100. Demirtas-Tatlidede A, Vahabzadeh-Hagh AM, Bernabeu M, Tormos JM, Pascual-Leone A. Noninvasive brain stimulation in traumatic brain injury. J Head Trauma Rehabil. (2012) 27:274-92. doi: 10.1097/HTR.0b013e318217df55

101. Han CL, Hu W, Stead M, Zhang T, Zhang JG, Worrell GA, et al. Electrical stimulation of hippocampus for the treatment of refractory temporal lobe epilepsy. Brain Res Bull. (2014) 109:13-21. doi: 10.1016/j.brainresbull.2014.08.007

102. Abraham WC. Metaplasticity: tuning synapses and networks for plasticity. Nat Rev Neurosci. (2008) 9:387-99. doi: 10.1038/nrn2356

103. Müller-Dahlhaus F, Ziemann U. Metaplasticity in human cortex. Neurosci. (2015) 21:185-202. doi: 10.1177/1073858414526645

104. Turrigiano GG, Nelson SB. Homeostatic plasticity in the developing nervous system. Nat Rev Neurosci. (2004) 5:97-107. doi: 10.1038/nrn1327

105. Bienenstock EL, Cooper LN, Munro PW. Theory for the development of neuron selectivity: Orientation specificity and binocular interaction in visual cortex. $J$ Neurosci. (1982) 2:32-48. doi: 10.1523/JNEUROSCI.02-01-00032.1982

106. Morgante F, Espay AJ, Gunraj C, Lang AE, Chen R. Motor cortex plasticity in Parkinson's disease and levodopa-induced dyskinesias. Brain. (2006) 129:1059-69. doi: 10.1093/brain/awl031

107. Udupa K, Chen R. Motor cortical plasticity in Parkinson's disease. Front Neurol. (2013) 4:128. doi: 10.3389/fneur.2013.00128

108. Ueki Y, Mima T, Ali Kotb M, Sawada H, Saiki H, Ikeda A, et al. Altered plasticity of the human motor cortex in Parkinson's disease. Ann Neurol. (2006) 59:60-71. doi: 10.1002/ana.20692

109. Quartarone A, Siebner HR, Rothwell JC. Task-specific hand dystonia: can too much plasticity be bad for you? Trends Neurosci. (2006) 29:1929. doi: 10.1016/j.tins.2006.02.007

110. Weise D. The two sides of associative plasticity in writer's cramp. Brain. (2006) 129:2709-21. doi: 10.1093/brain/awl221

111. Mori F, Rossi S, Piccinin S, Motta C, Mango D, Kusayanagi H, et al. Synaptic plasticity and PDGF signaling defects underlie clinical progression in multiple sclerosis. J Neurosci. (2013) 33:19112-9. doi: 10.1523/JNEUROSCI.2536-13.2013

112. Di Lazzaro V, Profice P, Pilato F, Capone F, Ranieri F, Pasqualetti P, et al. Motor cortex plasticity predicts recovery in acute stroke. Cereb Cortex. (2010) 20:1523-8. doi: 10.1093/cercor/bhp216

113. Pierelli F, Iacovelli E, Bracaglia M, Serrao M, Coppola G. Abnormal sensorimotor plasticity in migraine without aura patients. Pain. (2013) 154:1738-42. doi: 10.1016/j.pain.2013.05.023

114. Koch G, Mori F, Marconi B, Codecà C, Pecchioli C, Salerno S, et al. Changes in intracortical circuits of the human motor cortex following theta burst stimulation of the lateral cerebellum. Clin Neurophysiol. (2008) 119:255969. doi: 10.1016/j.clinph.2008.08.008 
115. Daskalakis ZJ, Christensen BK, Fitzgerald PB, Chen R. Dysfunctional neural plasticity in patients with schizophrenia. Arch Gen Psychiatry. (2008) 65:378. doi: 10.1001/archpsyc.65.4.378

116. Frantseva M V., Fitzgerald PB, Chen R, Moller B, Daigle M, Daskalakis ZJ. Evidence for impaired long-term potentiation in schizophrenia and its relationship to motor skill leaning. Cereb Cortex. (2008) 18:990996. doi: $10.1093 /$ cercor/bhm151

117. Hasan A, Nitsche MA, Rein B, Schneider-Axmann T, Guse B, Gruber O, et al. Dysfunctional long-term potentiation-like plasticity in schizophrenia revealed by transcranial direct current stimulation. Behav Brain Res. (2011) 224:15-22. doi: 10.1016/j.bbr.2011.05.017

118. Barr MS, Farzan F, Wing VC, George TP, Fitzgerald PB, Daskalakis ZJ. Repetitive transcranial magnetic stimulation and drug addiction. Int Rev Psychiatry. (2011) 23:454-66. doi: 10.3109/09540261.2011.618827

119. Liebetanz D, Nitsche MA, Lang N, Antal A, Paulus W, Tergau F. Safety criteria for transcranial direct current stimulation (tDCS) in humans. Clin Neurophysiol. (2003) 114:2220-2. doi: 10.1016/S1388-2457(03) 00235-9

120. Nitsche MA, Niehaus L, Hoffmann KT, Hengst S, Liebetanz D, Paulus W, et al. MRI study of human brain exposed to weak direct current stimulation of the frontal cortex. Clin Neurophysiol. (2004) 115:241923. doi: 10.1016/j.clinph.2004.05.001

121. Faria P, Hallett M, Miranda PC. A finite element analysis of the effect of electrode area and inter-electrode distance on the spatial distribution of the current density in tDCS. J Neural Eng. (2011) 8:066017. doi: 10.1088/1741-2560/8/6/066017

122. Nitsche MA, Seeber A, Frommann K, Klein CC, Rochford C, Nitsche MS, et al. Modulating parameters of excitability during and after transcranial direct current stimulation of the human motor cortex. J Physiol. (2005) 568:291-303. doi: 10.1113/jphysiol.2005.092429

123. Lefaucheur JP. Principles of therapeutic use of transcranial and epidural cortical stimulation. Clin Neurophysiol. (2008) 119:2179-84. doi: 10.1016/j.clinph.2008.07.007

124. Boros K, Poreisz C, Münchau A, Paulus W, Nitsche MA. Premotor transcranial direct current stimulation (tDCS) affects primary motor excitability in humans. Eur $J$ Neurosci. (2008) 27:1292-300. doi: 10.1111/j.1460-9568.2008.06090.x

125. Vines BW, Cerruti C, Schlaug G. Dual-hemisphere tDCS facilitates greater improvements for healthy subjects' non-dominant hand compared to uni-hemisphere stimulation. BMC Neurosci. (2008) 9:103. doi: 10.1186/1471-2202-9-103

126. Marshall L. Transcranial direct current stimulation during sleep improves declarative memory. J Neurosci. (2004) 24:998592. doi: 10.1523/JNEUROSCI.2725-04.2004

127. Ardolino G, Bossi B, Barbieri S, Priori A. Non-synaptic mechanisms underlie the after-effects of cathodal transcutaneous direct current stimulation of the human brain. J Physiol. (2005) 568:653-63. doi: 10.1113/jphysiol.2005.088310

128. Montez T, Poil SS, Jones BF, Manshanden I, Verbunt JPA, Van Dijk BW, et al. Altered temporal correlations in parietal alpha and prefrontal theta oscillations in early-stage Alzheimer disease. Proc Natl Acad Sci USA. (2009) 106:1614-9. doi: 10.1073/pnas.0811699106

129. Gili T, Cercignani M, Serra L, Perri R, Giove F, Maraviglia B, et al. Regional brain atrophy and functional disconnection across Alzheimer's disease evolution. J Neurol Neurosurg Psychiatry. (2011) 82:5866. doi: 10.1136/jnnp.2009.199935

130. Grady CL, Furey ML, Pietrini P, Horwitz B, Rapoport SI. Altered brain functional connectivity and impaired short-term memory in Alzheimer's disease. Brain. (2001) 124:739-56. doi: 10.1093/brain/124.4.739

131. Polanía R, Nitsche MA, Paulus W. Modulating functional connectivity patterns and topological functional organization of the human brain with transcranial direct current stimulation. Hum Brain Mapp. (2011) 32:123649. doi: $10.1002 / \mathrm{hbm} .21104$

132. Klostermann F, Nikulin V V., Kühn AA, Marzinzik F, Wahl M, Pogosyan A, et al. Task-related differential dynamics of EEG alpha- and beta-band synchronization in cortico-basal motor structures. Eur J Neurosci. (2007) 25:1604-15. doi: 10.1111/j.1460-9568.2007.05417.x
133. Uhlhaas PJ, Singer W. Neural synchrony in brain disorders: relevance for cognitive dysfunctions and pathophysiology. Neuron. (2006) 52:15568. doi: 10.1016/j.neuron.2006.09.020

134. Peña-Gómez C, Sala-Lonch R, Junqué C, Clemente IC, Vidal D, Bargalló N, et al. Modulation of large-scale brain networks by transcranial direct current stimulation evidenced by resting-state functional MRI. Brain Stimul. (2012) 5:252-63. doi: 10.1016/j.brs.2011.08.006

135. Polanía R, Paulus W, Nitsche MA. Modulating cortico-striatal and thalamocortical functional connectivity with transcranial direct current stimulation. Hum Brain Mapp. (2012) 33:2499-508. doi: 10.1007/978-3-662-45797-9_7

136. Gammaitoni L, Hänggi P, Jung P, Marchesoni F. Stochastic resonance. Rev Mod Phys. (1998) 70:223-87. doi: 10.1103/RevModPhys.70.223

137. Kitajo K, Nozaki D, Ward LM, Yamamoto Y. Behavioral stochastic resonance within the human brain. Phys Rev Lett. (2003) 90:218103. doi: 10.1103/PhysRevLett.90.218103

138. Fertonani A, Miniussi C. Transcranial electrical stimulation. Neurosci. (2017) 23:109-23. doi: 10.1177/1073858416631966

139. Papa M, De Luca C, Petta F, Alberghina L, Cirillo G. Astrocyte-neuron interplay in maladaptive plasticity. Neurosci Biobehav Rev. (2014) 42:3554. doi: 10.1016/j.neubiorev.2014.01.010

140. Lee E, Chung W-S. Glial control of synapse number in healthy and diseased brain. Front Cell Neurosci. (2019) 13:42. doi: 10.3389/fncel.2019.00042

141. Phatnani H, Maniatis T. Astrocytes in neurodegenerative disease: table 1. Cold Spring Harb Perspect Biol. (2015) 7:a020628. doi: 10.1101/cshperspect.a020628

142. Liddelow SA, Barres BA. Reactive astrocytes: production, function, and therapeutic potential. Immunity. (2017) 46:95767. doi: 10.1016/j.immuni.2017.06.006

143. Li Q, Barres BA. Microglia and macrophages in brain homeostasis and disease. Nat Rev Immunol. (2018) 18:225-42. doi: 10.1038/nri.2017.125

144. Hong S, Beja-Glasser VF, Nfonoyim BM, Frouin A, Li S, Ramakrishnan $S$, et al. Complement and microglia mediate early synapse loss in Alzheimer mouse models. Science. (2016) 352:712-6. doi: 10.1126/science. aad8373

145. Shi Q, Chowdhury S, Ma R, Le KX, Hong S, Caldarone BJ, et al. Complement C3 deficiency protects against neurodegeneration in aged plaque-rich APP/PS1 mice. Sci Transl Med. (2017) 9:eaaf6295. doi: 10.1126/scitranslmed.aaf6295

146. Kullmann S, Kleinridders A, Small DM, Fritsche A, Häring H-U, Preissl $\mathrm{H}$, et al. Central nervous pathways of insulin action in the control of metabolism and food intake. Lancet Diabetes Endocrinol. (2020) 8:52434. doi: 10.1016/S2213-8587(20)30113-3

147. Srikanth V, Sinclair AJ, Hill-Briggs F, Moran C, Biessels GJ. Type 2 diabetes and cognitive dysfunction-towards effective management of both comorbidities. Lancet Diabetes Endocrinol. (2020) 8:535-45. doi: 10.1016/S2213-8587(20)30118-2

148. Colangelo AM, Cirillo G, Lavitrano ML, Alberghina L, Papa M. Targeting reactive astrogliosis by novel biotechnological strategies. Biotechnol Adv. (2012) 30:261-71. doi: 10.1016/j.biotechadv.2011.06.016

149. Rueger MA, Keuters MH, Walberer M, Braun R, Klein R, Sparing R, et al. Multi-session transcranial direct current stimulation (tDCS) Elicits inflammatory and regenerative processes in the rat brain. PLoS ONE. (2012) 7:e43776. doi: 10.1371/journal.pone.0043776

150. Pikhovych A, Stolberg NP, Jessica Flitsch L, Walter HL, Graf R, Fink GR, et al. Transcranial direct current stimulation modulates neurogenesis and microglia activation in the mouse brain. Stem Cells Int. (2016) 2016:19. doi: $10.1155 / 2016 / 2715196$

151. Spezia Adachi LN, Caumo W, Laste G, Fernandes Medeiros L, Ripoll Rozisky J, de Souza A, et al. Reversal of chronic stress-induced pain by transcranial direct current stimulation (tDCS) in an animal model. Brain Res. (2012) 1489:17-26. doi: 10.1016/j.brainres.2012.10.009

152. Barbour B, Brew H, Attwell D. Electrogenic glutamate uptake in glial cells is activated by intracellular potassium. Nature. (1988) 335:4335. doi: 10.1038/335433a0

153. Dallérac G, Chever O, Rouach N. How do astrocytes shape synaptic transmission? Insights from electrophysiology. Front Cell Neurosci. (2013) 7:159. doi: 10.3389/fncel.2013.00159 
154. Monai H, Hirase H. Astrocytic calcium activation in a mouse model of tDCS-Extended discussion. Neurogenesis. (2016) 3:e1240055. doi: 10.1080/23262133.2016.1240055

155. Borgens RB, Shi R, Mohr TJ, Jaeger CB. Mammalian cortical astrocytes align themselves in a physiological voltage gradient. Exp Neurol. (1994) 128:41-9. doi: 10.1006/exnr.1994.1111

156. Alexander JK, Fuss B, Colello RJ. Electric field-induced astrocyte alignment directs neurite outgrowth. Neuron Glia Biol. (2006) 2:93103. doi: 10.1017/S1740925X0600010X

157. Moriarty LJ, Borgens RB. An oscillating extracellular voltage gradient reduces the density and influences the orientation of astrocytes in injured mammalian spinal cord. J Neurocytol. (2001) 30:45-57. doi: 10.1023/A:1011917424450

158. Cicchetti F, Barker RA. The glial response to intracerebrally delivered therapies for neurodegenerative disorders: is this a critical issue? Front Pharmacol. (2014) 5:139. doi: 10.3389/fphar.2014.00139

159. Cambiaghi M, Velikova S, Gonzalez-Rosa JJ, Cursi M, Comi G, Leocani L. Brain transcranial direct current stimulation modulates motor excitability in mice. Eur J Neurosci. (2010) 31:704-9. doi: 10.1111/j.1460-9568.2010.07092.x

160. Herrmann CS, Rach S, Neuling T, Strüber D. Transcranial alternating current stimulation: a review of the underlying mechanisms and modulation of cognitive processes. Front Hum Neurosci. (2013) 7:279. doi: 10.3389/fnhum.2013.00279

161. Klink K, Paßmann S, Kasten FH, Peter J. The modulation of cognitive performasnce with transcranial alternating current stimulation: a systematic review of frequency-specific effects. Brain Sci. (2020) 10:932. doi: 10.3390/brainsci10120932

162. Steinmann S, Leicht G, Mulert C. The interhemispheric miscommunication theory of auditory verbal hallucinations in schizophrenia. Int J Psychophysiol. (2019) 145:83-90. doi: 10.1016/j.ijpsycho.2019.02.002

163. Wilkening A, Kurzeck A, Dechantsreiter E, Padberg F, Palm U. Transcranial alternating current stimulation for the treatment of major depression during pregnancy. Psychiatry Res. (2019) 279:399-400. doi: 10.1016/j.psychres.2019.06.009

164. Klimke A, Nitsche MA, Maurer K, Voss U. Case report: successful treatment of therapy-resistant OCD with application of transcranial alternating current stimulation (tACS). Brain Stimul. (2016) 9:4635. doi: 10.1016/j.brs.2016.03.005

165. van Deursen JA, Vuurman EFPM, Verhey FRJ, van Kranen-Mastenbroek VHJM, Riedel WJ. Increased EEG gamma band activity in Alzheimer's disease and mild cognitive impairment. J Neural Transm. (2008) 115:130111. doi: 10.1007/s00702-008-0083-y

166. Naro A, Corallo F, De Salvo S, Marra A, Di Lorenzo G, Muscarà N, et al. Promising role of neuromodulation in predicting the progression of mild cognitive impairment to dementia. J Alzheimer's Dis. (2016) 53:137588. doi: 10.3233/JAD-160305

167. Chai Z, Ma C, Jin X. Cortical stimulation for treatment of neurological disorders of hyperexcitability: A role of homeostatic plasticity. Neural Regen Res. (2019) 14:34-8. doi: 10.4103/1673-5374.243696

168. Nitsche MA, Paulus W. Excitability changes induced in the human motor cortex by weak transcranial direct current stimulation. J Physiol. (2000) 527:633-9. doi: 10.1111/j.1469-7793.2000.t01-1-00633.x

169. Fernández A, Maestú F, Amo C, Gil P, Fehr T, Wienbruch C, et al. Focal temporoparietal slow activity in Alzheimer's disease revealed by magnetoencephalography. Biol Psychiatry. (2002) 52:764-70. doi: 10.1016/S0006-3223(02)01366-5

170. Jiang T, Xu RX, Zhang AW, Di W, Xiao ZJ, Miao JY, et al. Effects of transcranial direct current stimulation on hemichannel pannexin-1 and neural plasticity in rat model of cerebral infarction. Neuroscience. (2012) 226:421-6. doi: 10.1016/j.neuroscience.2012.09.035

171. Yoon KJ, Oh BM, Kim DY. Functional improvement and neuroplastic effects of anodal transcranial direct current stimulation (tDCS) delivered 1 day vs. 1 week after cerebral ischemia in rats. Brain Res. (2012) 1452:6172. doi: 10.1016/j.brainres.2012.02.062

172. Shaw M, Pawlak N, Choi C, Khan N, Datta A, Bikson M. Transcranial Direct Current Stimulation (tDCS) induces acute changes in brain metabolism. Brain Stimul. (2019) 12:518. doi: 10.1016/j.brs.2018.12.703

173. Sun DA, Sombati S, Blair RE, Delorenzo RJ. Calcium-dependent epileptogenesis in an in vitro model of stroke-induced "epilepsy." Epilepsia. (2002) 43:1296-305. doi: 10.1046/j.1528-1157.2002.09702.x

174. Pineda E, Shin D, Sankar R, Mazarati AM. Comorbidity between epilepsy and depression: experimental evidence for the involvement of serotonergic, glucocorticoid, and neuroinflammatory mechanisms. Epilepsia. (2010) 51:110-4. doi: 10.1111/j.1528-1167.2010.02623.x

175. Yamamoto J, Ikeda A, Kinoshita M, Matsumoto R, Satow T, Takeshita $\mathrm{K}$, et al. Low-frequency electric cortical stimulation decreases interictal and ictal activity in human epilepsy. Seizure. (2006) 15:520-7. doi: 10.1016/j.seizure.2006.06.004

176. Liebetanz D, Klinker F, Hering D, Koch R, Nitsche MA, Potschka H, et al. Anticonvulsant effects of transcranial direct-current stimulation (tDCS) in the rat cortical ramp model of focal epilepsy. Epilepsia. (2006) 47:121624. doi: 10.1111/j.1528-1167.2006.00539.x

177. Yook S-W, Park S-H, Seo J-H, Kim S-J, Ko M-H. Suppression of seizure by cathodal transcranial direct current stimulation in an epileptic patient - a case report -. Ann Rehabil Med. (2011) 35:57982. doi: 10.5535/arm.2011.35.4.579

178. Gschwind M, Seeck M. Modern management of seizures and epilepsy. Swiss Med Wkly. (2016) 146:w14310. doi: 10.4414/smw.2016.14310

179. Benussi A, Dell'Era V, Cantoni V, Bonetta E, Grasso R, Manenti $\mathrm{R}$, et al. Cerebello-spinal tDCS in ataxia A randomized, doubleblind, sham-controlled, crossover trial. Neurology. (2018) 91:E1090E101. doi: 10.1212/WNL.0000000000006210

180. Jayaram G, Tang B, Pallegadda R, Vasudevan E, Celnik P, Bastian A. Modulating locomotor adaptation with cerebellar stimulation. J Neurophysiol. (2012) 107:2950-7. doi: 10.1152/jn.00645.2011

181. Priori A, Ciocca M, Parazzini M, Vergari M, Ferrucci R. Transcranial cerebellar direct current stimulation and transcutaneous spinal cord direct current stimulation as innovative tools for neuroscientists. J Physiol. (2014) 592:3345-69. doi: 10.1113/jphysiol.2013.270280

182. Truini A, Romaniello A, Galeotti F, Iannetti GD, Cruccu G. Laser evoked potentials for assessing sensory neuropathy in human patients. Neurosci Lett. (2004) 361:25-8. doi: 10.1016/j.neulet.2003.12.008

183. Lim CY, Shin HI. Noninvasive DC stimulation on neck changes MEP. Neuroreport. (2011) 22:819-23. doi: 10.1097/WNR.0b013e3283 4b939d

184. ElBasiouny SM, Mushahwar VK. Suppressing the excitability of spinal motoneurons by extracellularly applied electrical fields: insights from computer simulations. J Appl Physiol. (2007) 103:1824-36. doi: 10.1152/japplphysiol.00362.2007

185. Hounsgaard J, Kiehn O. Calcium spikes and calcium plateaux evoked by differential polarization in dendrites of turtle motoneurones in vitro. J Physiol. (1993) 468:245-59. doi: 10.1113/jphysiol.1993.sp019769

Conflict of Interest: The authors declare that the research was conducted in the absence of any commercial or financial relationships that could be construed as a potential conflict of interest.

Copyright (c) 2021 Korai, Ranieri, Di Lazzaro, Papa and Cirillo. This is an openaccess article distributed under the terms of the Creative Commons Attribution License (CC BY). The use, distribution or reproduction in other forums is permitted, provided the original author(s) and the copyright owner(s) are credited and that the original publication in this journal is cited, in accordance with accepted academic practice. No use, distribution or reproduction is permitted which does not comply with these terms. 